\title{
Inter-annual variation of carbon uptake by a plantation oak woodland in south-eastern England
}

\author{
M. Wilkinson ${ }^{1}$, E. L. Eaton ${ }^{1}$, M. S. J. Broadmeadow ${ }^{2}$, and J. I. L. Morison ${ }^{1}$ \\ ${ }^{1}$ Forest Research, Centre for Forestry and Climate Change, Alice Holt Lodge, Farnham, Surrey, GU10 4LH, UK \\ ${ }^{2}$ Forestry Commission, Alice Holt Lodge, Farnham, Surrey, GU10 4LH, UK
}

Correspondence to: M. Wilkinson (matthew.wilkinson@ forestry.gsi.gov.uk)

Received: 21 June 2012 - Published in Biogeosciences Discuss.: 31 July 2012

Revised: 21 November 2012 - Accepted: 23 November 2012 - Published: 21 December 2012

\begin{abstract}
The carbon balance of an 80-yr-old deciduous oak plantation in the temperate oceanic climate of the south-east of Great Britain was measured by eddy covariance over 12 yr (1999-2010). The mean annual net ecosystem productivity (NEP) was $486 \mathrm{~g} \mathrm{C} \mathrm{m}^{-2} \mathrm{yr}^{-1}$ (95\% CI of $\pm 73 \mathrm{~g} \mathrm{C} \mathrm{m}^{-2} \mathrm{yr}^{-1}$ ), and this was partitioned into a gross primary productivity (GPP) of $2034 \pm 145 \mathrm{~g} \mathrm{C} \mathrm{m}^{-2} \mathrm{yr}^{-1}$, over a $165( \pm 6)$ day growing season, and an annual loss of carbon through respiration and decomposition (ecosystem respiration, $R_{\mathrm{eco}}$ ) of $1548 \pm 122 \mathrm{~g} \mathrm{C} \mathrm{m}^{-2} \mathrm{yr}^{-1}$. Although the maximum variation of NEP between years was large ( $333 \mathrm{~g} \mathrm{C} \mathrm{m}^{-2} \mathrm{yr}^{-1}$ ), the ratio of $R_{\mathrm{eco}} / \mathrm{GPP}$ remained relatively constant $(0.76 \pm 0.02 \mathrm{CI})$. Some anomalies in the annual patterns of the carbon balance could be linked to particular weather events, such as low summer solar radiation and low soil moisture content (values below $30 \%$ by volume). The European-wide heat wave and drought of 2003 did not reduce the NEP of this woodland because of good water supply from the surface-water gley soil. The inter-annual variation in estimated intercepted radiation only accounted for $\sim 47 \%$ of the variation in GPP, although a significant relationship $(p<0.001)$ was found between peak leaf area index and annual GPP, which modified the efficiency with which incident radiation was used in net $\mathrm{CO}_{2}$ uptake. Whilst the spring start and late autumn end of the net $\mathrm{CO}_{2}$ uptake period varied substantially (range of 24 and 27 days respectively), annual GPP was not related to growing season length. Severe outbreaks of defoliating moth caterpillars, mostly Tortrix viridana $\mathrm{L}$. and Operophtera brumata $\mathrm{L}$., caused considerable damage to the forest canopy in 2009 and 2010, resulting in reduced GPP in these two years. Inter-annual variation in the sensitivity of $R_{\text {eco }}$ to temperature was found to be
\end{abstract}

strongly related to summer soil moisture content. The eddy covariance estimates of NEP closely matched mensurationbased estimates, demonstrating that this forest was a substantial sink of carbon over the 12-yr measurement period.

\section{Introduction}

Many terrestrial ecosystems, including forests, are sinks for carbon (C) (Unger et al., 2009), and globally between 1990 and 2007 forests were estimated to have a net sequestration of $1.1 \pm 0.8 \mathrm{Pg} \mathrm{Cyr}^{-1}$ (Pan et al., 2011), equivalent to oneseventh of emissions from fossil fuel combustion and cement production (Reich, 2011). Forests therefore have a fundamental role in helping to regulate atmospheric $\mathrm{CO}_{2}$ concentrations, and an improved understanding of the underlying processes is needed to inform the development of climate change mitigation strategies (Nabuurs et al., 2007). In the medium to long term, a growing forest stand will be a net carbon sink, but at shorter timescales and as they react to unfavourable weather conditions, they can also act as a source (Valentini et al., 2000). For example, the severe drought and extreme high temperatures experienced in Europe over the summer of 2003 led to an estimated net release from the continent's forests of $0.5 \mathrm{Pg} \mathrm{Cyr}^{-1}$ (Ciais et al., 2005). Forest disturbance, changes in local climate or in phenology may also lead to a long-term forest carbon sink temporarily becoming a carbon source (Powell et al., 2006; Pereira et al., 2007; Noormets et al., 2008).

While forest mensuration methods are well suited to quantifying the long-term growth of forest stands (e.g. at $5 \mathrm{yr}$ intervals), the infrequency with which measurements are 
usually made means that they are unable to give reliable information about inter-annual variation in growth rates. Furthermore, as mensuration methods typically show only the net effect on the tree components, they do not give information about the $\mathrm{C}$ balance of whole ecosystems or about the effects of disturbance and recovery. Networks of longterm, continuous, direct measurements of $\mathrm{CO}_{2}$ fluxes using the eddy covariance method have become a powerful tool in improving the understanding of $\mathrm{C}$ exchange between forests and the atmosphere (Baldocchi et al., 2001), and provide valuable information relating to their daily and seasonal changes and about the impact of management. Our understanding of the size of sink and extent of inter-annual variation is increasing as data from eddy covariance studies in forests in excess of $10 \mathrm{yr}$ duration become available (e.g. Ito et al., 2005; Dunn et al., 2007; Ilvesniemi et al., 2009). Key aspects now being revealed include the following: impacts of climate change (Urbanski et al., 2007); the role of weather anomalies (Saigusa et al., 2008; Teklemariam et al., 2009); effects of pests and diseases (Allard et al., 2008) and the role of management (Saunders et al., 2012).

In this paper we present the results from $12 \mathrm{yr}$ (1999-2010) of eddy covariance measurements of $\mathrm{CO}_{2}$ flux above an 80-yr-old lowland oak woodland in a mild, temperate, oceanic climate in south-eastern England. The annual sums of net ecosystem productivity (NEP) and its component assimilatory (gross primary productivity, GPP) and respiratory fluxes (ecosystem respiration, $R_{\text {eco }}$ ) are given. The paper also examines the causes of inter-annual variability of the partitioned fluxes, and assesses the relationship with key climatic and biotic drivers.

\section{Materials and instrumentation}

\subsection{Site description}

The site is located in the Straits Inclosure, Alice Holt Research Forest, UK $\left(51^{\circ} 07^{\prime} \mathrm{N}, 0^{\circ} 51^{\prime} \mathrm{W}\right)$, close to the Alice Holt Research Station in south-eastern England (Fig. 1). The site is affiliated with the FLUXNET network and is also included in several other monitoring and research projects: it is a Level-II observation plot of the European network (ICP Forests) programme (http://icp-forests.net) and a UK Environmental Change Network (ECN) site (http://www.ecn.ac.uk). The inclosure is a flat area with an elevation of $80 \mathrm{~m}$; the surrounding landscape consists of mixed lowland woodland and both arable and pasture agricultural land. The site is managed by Forest Research, the research agency of the British Government's Forestry Commission.

Early maps and records show that the western half of the Straits Inclosure was wooded in 1787, with the eastern part under agricultural management. The whole 90-ha inclosure was planted in the 1820s with oak (Schlich, 1905)

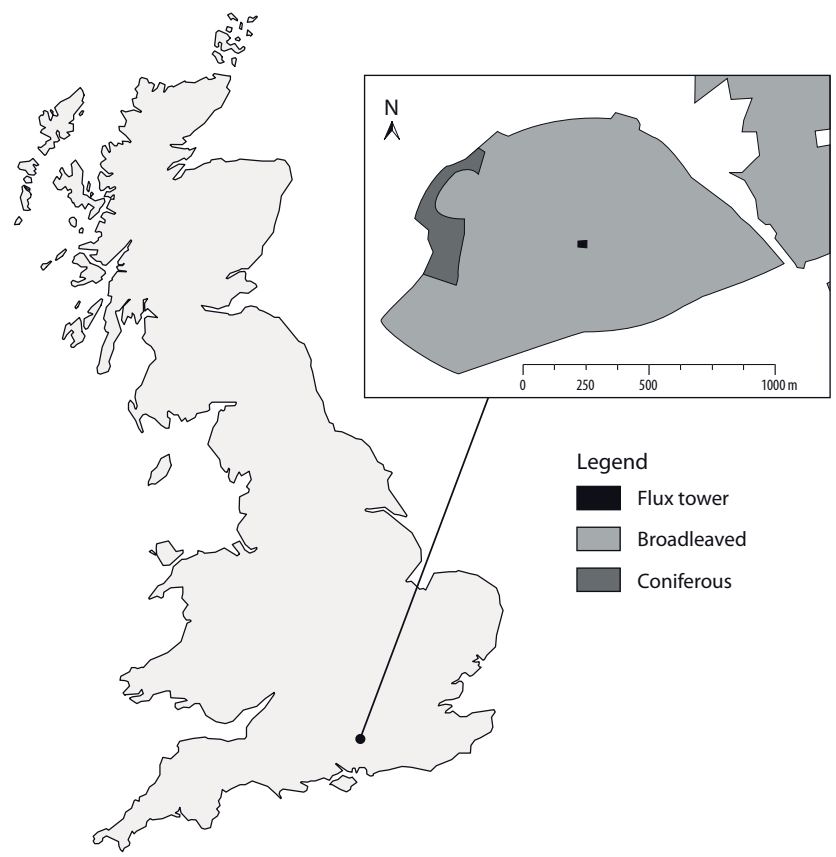

Fig. 1. Map of Great Britain with inset figure showing the location and layout of the Straits Inclosure.

and then replanted in the 1930s so that it is now a relatively homogeneous forest block managed as a commercial lowland oak forest. The main tree species is Quercus robur L., but other species, including European ash (Fraxinus excelsior L.), Q. petraea (Mattuschka) Liebl. and Q. cerris L., are present. There is a small area of mixed conifers consisting of Corsican pine (Pinus nigra subsp. laricio Maire.) and Scots pine (Pinus sylvestris L.) at the north-west edge of the woodland, and isolated pockets of Japanese red cedar (Cryptomeria japonica (L.f.) D. Don) are also present in the eastern area. The understorey is dominated by hazel (Corylus avellana L.) and hawthorn (Crataegus monogyna Jacq.; Pitman and Broadmeadow, 2001). The soil is a surface-water gley (Pyatt, 1982), with a depth of $80 \mathrm{~cm}$ to the $\mathrm{C}$ horizon of the Cretaceous clay. Soil $\mathrm{pH}$ is 4.6 and 4.8 in the organic and mineral horizons respectively, and the soil organic $\mathrm{C}$ stock measured in the top $30 \mathrm{~cm}$ in 2004 was $87 \mathrm{t} \mathrm{Cha}^{-1}$ (Benham et al., 2012), and to $1 \mathrm{~m}$ depth in 1997 was $157 \mathrm{tC} \mathrm{ha}^{-1}$ (Table 3.7; Morison et al., 2012). Periodic tree measurements have been carried out at seven vegetation sampling plots as part of the ECN monitoring programme (Table 1). In addition, 18 forest mensuration plots ( $8 \mathrm{~m}$ in radius) were established in the western half of the inclosure during 2009; a density of 450 canopy trees per hectare was recorded, with a basal area of $29.7 \mathrm{~m}^{2}$. In the recent past, different parts of the site have been thinned in 1991, 1995, 2000 and 2007.

Eddy covariance measurements of $\mathrm{CO}_{2}$, sensible heat and water vapour flux were carried out at $28 \mathrm{~m}$ above ground level on a free-standing 26-m-high square-section mast (Gigalite 4, Litestructures Ltd, Pontefract, UK) located near to 
Table 1. Mean annual biometric mensuration data for understorey and canopy tree species at the Straits Inclosure, Alice Holt Forest, for the period 1994-2011.

\begin{tabular}{l|rrr|rr}
\hline Year & \multicolumn{3}{|c|}{ Shrubs } & \multicolumn{2}{c}{ Canopy Trees } \\
\cline { 2 - 6 } & $\begin{array}{r}\text { Crataegus } \\
\text { monogyna }\end{array}$ & $\begin{array}{r}\text { Corylus } \\
\text { avellana }\end{array}$ & $\begin{array}{r}\text { Ilex } \\
\text { aquifolium }\end{array}$ & $\begin{array}{r}\text { Fraxinus } \\
\text { excelsior }\end{array}$ & $\begin{array}{r}\text { Quercus } \\
\text { robur }\end{array}$ \\
\hline \multicolumn{2}{l}{ Height (m) } & & & & \\
\hline 1994 & 3.5 & 6.8 & $\mathrm{Na}$ & 17.8 & 16.1 \\
2002 & 3.9 & 7.4 & 5.4 & 19.9 & 19.6 \\
2011 & 7.4 & 6.2 & 8.6 & 21.6 & 21.1 \\
\hline Diameter (cm) & & & & & \\
\hline 1994 & 6.0 & 6.4 & $\mathrm{Na}$ & 20.8 & 22.5 \\
2002 & 4.6 & 6.0 & 7.5 & 23.9 & 28.6 \\
2011 & 7.3 & 4.9 & 11.6 & 26.5 & 29.6 \\
\hline
\end{tabular}

$\mathrm{Na}=$ not available

the centre of the inclosure (Fig. 1) providing a fetch over the woodland of $500 \mathrm{~m}, 700 \mathrm{~m}, 350 \mathrm{~m}$ and $600 \mathrm{~m}$ to the N, E, $\mathrm{S}$ and $\mathrm{W}$ respectively. Additional measurements of climatic variables were recorded from the mast or from the ground nearby (see below). The long-term mean (1971-2000) screen annual air temperature was $9.6^{\circ} \mathrm{C}$ and the mean annual precipitation $779 \mathrm{~mm}$ at the UK Meteorological Office affiliated weather station, Alice Holt, Farnham $\left(51^{\circ} 10^{\prime} \mathrm{N}, 0^{\circ} 51^{\prime} \mathrm{W}\right)$, approximately $1.8 \mathrm{~km}$ from the measurement site.

\subsection{Instrumentation}

Half-hourly fluxes of energy (sensible and latent heat), momentum, $\mathrm{CO}_{2}$ and water vapour have been measured continuously using the eddy covariance technique (Moncrieff et al., 1997) since 1998. The system is comprised of a threedimensional sonic anemometer (model Solent R2, Gill Instruments, Lymington, UK) measuring wind vector components and a closed-path infrared $\mathrm{CO}_{2}$ and $\mathrm{H}_{2} \mathrm{O}$ analyser (IRGA, model LI-6262 until October 2005, LI-7000 thereafter, LI-COR Inc., Lincoln, NE USA) measuring atmospheric $\mathrm{CO}_{2}$ and $\mathrm{H}_{2} \mathrm{O}$ concentrations. Pure nitrogen was used as the zero $\mathrm{CO}_{2}$ concentration gas flowing through the IRGA reference cell. Sample air was drawn from the inlet port at a point close to the sonic anemometer (horizontal separation of $\sim 10 \mathrm{~cm}$ ) using a sample tube (Dekabon Ltd., Glasgow, UK) with an internal diameter of $6.15 \mathrm{~mm}$, through two inline 1 micron PTFE Teflon filters (Gelman Acro 50) at a rate of 5.5 $\mathrm{L} \mathrm{min}^{-1}$ by a small pump (Capex V2 SE, Charles Austen Pumps, Byfleet, Surrey, UK). Calibration of the IRGA using a reference standard gas was performed weekly. The raw high frequency data $(20.8 \mathrm{~Hz})$ were logged using the EdiSol software (Moncrieff et al., 1997), and for this study were available from 1 January 1999 through to 31 December 2010. The system was powered by battery, charged by solar panels and wind turbines until 31 May 2005, when mains power was installed, resulting in significant improvements to data collection.

Supporting environmental measurements recorded at the site included the following: wind speed and direction (model WA15, Vaisala, Helsinki, Finland), wet and dry bulb air temperature (model DTS-5, ELE International, Loveland, USA), above and below canopy solar radiation (tube solarimeters, Delta-T Devices, Cambridge, UK), global solar radiation (model CM2, Kipp \& Zonen B.V., Delft, Netherlands), net radiation (model DRN-301, ELE International, Loveland, USA), soil heat flux (model HFP01, Campbell Scientific Ltd, Loughborough, UK), soil temperature at $10 \mathrm{~cm}$ depth (2K Thermistor, Delta-T Devices) and soil moisture (model ThetaProbe ML2, Delta-T Devices). All measurements were logged at $10 \mathrm{~s}$ intervals, and half-hourly averages recorded using data loggers (DT 500, dataTaker, Thermo Fisher Scientific, Australia).

Leaf area index (LAI) was assessed using litterfall traps located within the Level-II forest-intensive monitoring plot approximately $450 \mathrm{~m}$ from the flux tower. Canopy litterfall (leaves, twigs, frass, acorns, etc.) was collected in 10 coneshaped traps held above the ground vegetation at height of $1.5 \mathrm{~m}$, each with a collecting surface area of $0.33 \mathrm{~m}^{2}$, and distributed randomly within the monitoring plot. Small cloth bags attached to the traps were collected every two weeks during the summer and autumn and subsequently sorted into their constituents. Leaf surface area was measured using a leaf area meter (model MK2, Delta-T Devices), and peak leaf areas back-calculated from cumulative litterfall (ICP Forests, 2004). Although the forest intensive monitoring plot has been subjected to a slightly different management regime than other areas of the forest, a comparison with litterfall traps from the area surrounding the mast (data not shown) indicates that the LAI values derived here give a good representation of the relative change in canopy density between years.

\subsection{Calculation of $\mathrm{CO}_{2}$ fluxes}

The raw eddy covariance data files were re-processed with the Edinburgh University micrometeorological software tool EdiRe (http://www.geos.ed.ac.uk/abs/research/ micromet/EdiRe) following the basic procedures used in the CarboEurope project (Aubinet et al., 2000). Two-angle velocity signal coordinate rotation was applied to ensure that the vertical velocity signal was orthogonal to the plane of mean air flow. The lag time of the sample from the intake point to the cell of the closed-path analyser was determined by maximising the covariance between the vertical wind velocity and scalar concentration. Virtual temperature derived from the speed of sound was corrected for water vapour (Hignett, 1992). In order to account for flux loss caused by signal damping inside the tube, limited time response and sensor separation, etc, the usual spectral corrections were applied (Moore, 1986; Leuning and Moncrieff, 1990; Lenschow and Raupach, 1991; Massman, 1991) to 
compute the corrected $\mathrm{CO}_{2}$ and water vapour fluxes. In addition, an angle of attack correction was applied to correct for sonic anemometer velocity calibration errors at large ( $> \pm 40$ degrees) angles of attack (Van der Molen et al., 2004).

Half-hourly net ecosystem exchange (NEE, $\mu \mathrm{mol} \mathrm{m}{ }^{-2} \mathrm{~s}^{-1}$ ) was calculated using the corrected $\mathrm{CO}_{2}$ flux, $F_{\mathrm{c}}$ as NEE $=F_{\mathrm{c}}+S_{\mathrm{c}}$, where $F_{\mathrm{c}}=\overline{w^{\prime} c^{\prime}}$ is the covariance between the vertical wind velocity and the atmospheric $\mathrm{CO}_{2}$ concentration, and $S c$ the rate of change in $\mathrm{CO}_{2}$ storage per unit ground area in the air column below the eddy covariance IRGA intake. The storage term was estimated by the simple approach using only the change in $\mathrm{CO}_{2}$ concentration measured at $28 \mathrm{~m}$ (Hollinger et al., 1994; Greco and Baldocchi, 1996):

$S_{\mathrm{c}}=\frac{\Delta c(z)}{\Delta t} \Delta z$,

where $\Delta c(z)$ is the change in $\mathrm{CO}_{2}$ molar density at height $z$, $\Delta t$ the time period $(30 \mathrm{~min})$ and $\Delta z$ the height of the eddy covariance sensor above ground $(28 \mathrm{~m})$.

After calculation of corrected NEE, and manual filtering of data for instrument failures and system maintenance, data filters were applied in order to remove extreme spikes, which were assumed to be not biologically valid data, an approach similar to that proposed by Papale et al. (2006) and Thomas et al. (2011). For each calendar year, NEE data were firstly split into either positive or negative values. Positive values greater than the mean positive value for the whole year plus three standard deviations were removed and the same approach applied to all negative values. A secondary stage data filter was then applied, removing positive values that were greater than the mean monthly value for that half-hourly period plus three standard deviations, and negative values less than the mean monthly value minus three deviations. Despiking filters were also applied to the latent heat flux $(<-100$ or $\left.>400 \mathrm{~W} \mathrm{~m}^{-2}\right)$ and to the sensible heat flux $(<-500$ or $>500 \mathrm{~W} \mathrm{~m}^{-2}$ ) NEE data when either of these criteria occurred were also removed.

A flux footprint probability analysis was carried out using the "footprint" calculation tool within EdiRe, which applies the model of Kormann and Meixner (2001) to a userspecified fetch. On average $65 \%$ of the daytime flux originated within $\sim 450 \mathrm{~m}$ of the tower, but at night this increased to $\sim 600 \mathrm{~m}$. Therefore, it is likely that a majority of the daytime flux originated from within the oak forest, particularly as the longest possible target fetch extends to over $800 \mathrm{~m}$ towards to the south-west of the tower, which is also the predominant $(24.6 \%)$ wind direction. However, we cannot exclude the possibility that fluxes were influenced by the adjoining agricultural land, especially when nighttime conditions were combined with southerly wind directions.

\subsection{Gap filling}

In order to create the continuous flux dataset required for carbon budgeting, and as an input for the partitioning of $\mathrm{CO}_{2}$ fluxes, it was necessary to replace the missing and deleted values with appropriate values ("gap-filling"). The marginal distribution sampling (MDS) method described in Reichstein et al. (2005) and accessed through the on-line CarboEurope gap filling tool was used (http://www.bgc-jena. mpg.de/ MDIwork/eddyproc/index.php). Whilst similar to the lookup table method (Falge et al., 2001), this approach also considers the temporal auto-correlation of the fluxes, replacing missing data with an average value under similar meteorological conditions. This method was chosen because it is widely accepted and has been employed by both CarboEurope and FLUXNET (Moffat et al., 2007; Papale et al., 2006). Half-hourly NEE values were screened against a friction velocity $\left(u^{*}\right)$ threshold using the method described by Reichstein et al. (2005) and implemented through the online gap filling tool. The dataset is split into six temperature categories of equal sample size and then further subdivided into 20 classes based on $u^{*}$ values. The $u^{*}$ threshold for each temperature class is calculated as the $u^{*}$ class where the nighttime flux reaches more than $95 \%$ of the average flux within the higher $u^{*}$ classes. The final threshold is defined as the median of the thresholds, and this procedure is applied to the subsets of four 3-month periods to account for seasonal variation of vegetation structure. The mean $u^{*}$ threshold for the period 1999-2010 calculated using this method was $0.17 \mathrm{~m} \mathrm{~s}^{-1}$. Where it is not possible to calculate a $u^{*}$ threshold, a default value of $0.4 \mathrm{~m} \mathrm{~s}^{-1}$ is used.

Although near-continuous meteorological data were collected, the occasional short-term gaps of $<1 \mathrm{~h}$ were filled by manual interpolation. Longer-term gaps in the meteorological data, caused by battery or logging failure, were filled using data from an automatic weather station at the nearby Alice Holt Research Station. Over the 12-yr period maintenance, data logging and power failure problems resulted in a mean annual loss of $18.5 \%$ of total available flux data. Quality control, primary, secondary and LE/H despiking routines removed a further $2.6 \%$, whilst $u^{*}$ filtering removed $17.1 \%$, resulting in a mean annual quality-controlled $\mathrm{CO}_{2}$ flux data availability of $61.8 \%$ (Table 2), and exceeding $50 \%$ in all years.

\section{5 $\mathrm{CO}_{2}$ flux partitioning}

The half-hourly quality-controlled NEE data were partitioned into gross primary productivity (GPP) and ecosystem respiration $\left(R_{\text {eco }}\right)$ using the on-line CarboEurope gap filling tool (Reichstein et al., 2005). The dataset is split into 10-day consecutive periods, and $R_{\text {eco }}$ is estimated using the LloydTaylor regression model (Lloyd and Taylor, 1994) between nighttime $\mathrm{CO}_{2}$ flux (global solar radiation $<20 \mathrm{~W} \mathrm{~m}^{-2}$ ) and air temperature. The estimated value of $R_{\text {eco }}$ is then assigned 
Table 2. Sources of annual data loss of $\mathrm{CO}_{2}$ flux measurements for the period 1999-2010 at the Straits Inclosure, Alice Holt Forest and quality-controlled (QC) data availability (\%).

\begin{tabular}{lllll}
\hline Year & $\begin{array}{l}\text { Power/ } \\
\text { logging failure }\end{array}$ & $\begin{array}{l}\text { QC/ } \\
\text { despiking }\end{array}$ & $u^{*}$ filtering & $\begin{array}{l}\text { QC flux } \\
\text { data }\end{array}$ \\
\hline 1999 & 13.9 & 2.3 & 17.7 & 66.1 \\
2000 & 21.7 & 2.5 & 15.5 & 60.3 \\
2001 & 27.0 & 2.5 & 11.0 & 59.5 \\
2002 & 24.9 & 2.3 & 13.9 & 58.9 \\
2003 & 18.8 & 3.1 & 23.3 & 54.8 \\
2004 & 13.0 & 3.5 & 15.2 & 68.3 \\
2005 & 8.2 & 3.9 & 12.7 & 75.2 \\
2006 & 23.7 & 0.1 & 14.2 & 62.1 \\
2007 & 19.5 & 2.3 & 19.2 & 59.0 \\
2008 & 12.9 & 5.3 & 30.2 & 51.5 \\
2009 & 23.9 & 2.3 & 18.5 & 55.3 \\
2010 & 15.0 & 0.8 & 13.7 & 70.5 \\
Mean & 18.5 & 2.6 & 17.1 & 61.8 \\
\hline
\end{tabular}

to the central time point of the averaging interval and linearly interpolated between time points. GPP is subsequently calculated as the difference between NEE and $R_{\text {eco }}$. By convention, NEP was defined as opposite in sign to NEE (Fig. 2).

\section{Results and analysis}

\subsection{Climatic conditions}

The average annual cycles of daily maximum air temperature $\left(T_{\max }\right)$, minimum air temperature $\left(T_{\min }\right)$ and incident solar radiation $\left(S_{\mathrm{g}}\right)$ recorded at the flux site are shown in Fig. $3 \mathrm{a}$ and the average daily soil moisture content and mean monthly precipitation from the nearby Alice Holt Research station in Fig. 3b. Collectively these illustrate the oceanic climate of the region, typified by mild winters, cool summers and a relatively uniform distribution of precipitation throughout the year. Using the Köppen climate classification system, the region is classified as "Cfb". The long-term (1971-2000) mean annual precipitation of $779 \mathrm{~mm}$ was exceeded in 8 out of the $12 \mathrm{yr}$, with the highest recorded amount falling in 2002 $(1046 \mathrm{~mm})$ and the lowest in $2005(590 \mathrm{~mm})$. The mean annual above-canopy solar radiation receipts were lowest in $2002\left(253 \mathrm{~W} \mathrm{~m}^{-2}\right)$ and highest in $2006\left(319 \mathrm{~W} \mathrm{~m}^{-2}\right)$. Longterm observations (1948-2009) from the Alice Holt weather station near the site have demonstrated a warming in mean surface air temperature (data not shown) of $\sim 0.2^{\circ} \mathrm{C}$ per decade, with higher rates of warming in winter and summer than in spring and autumn. Whilst there has been no overall change in annual precipitation, there has been a slight reduction in summer and an increase in winter levels over this period.

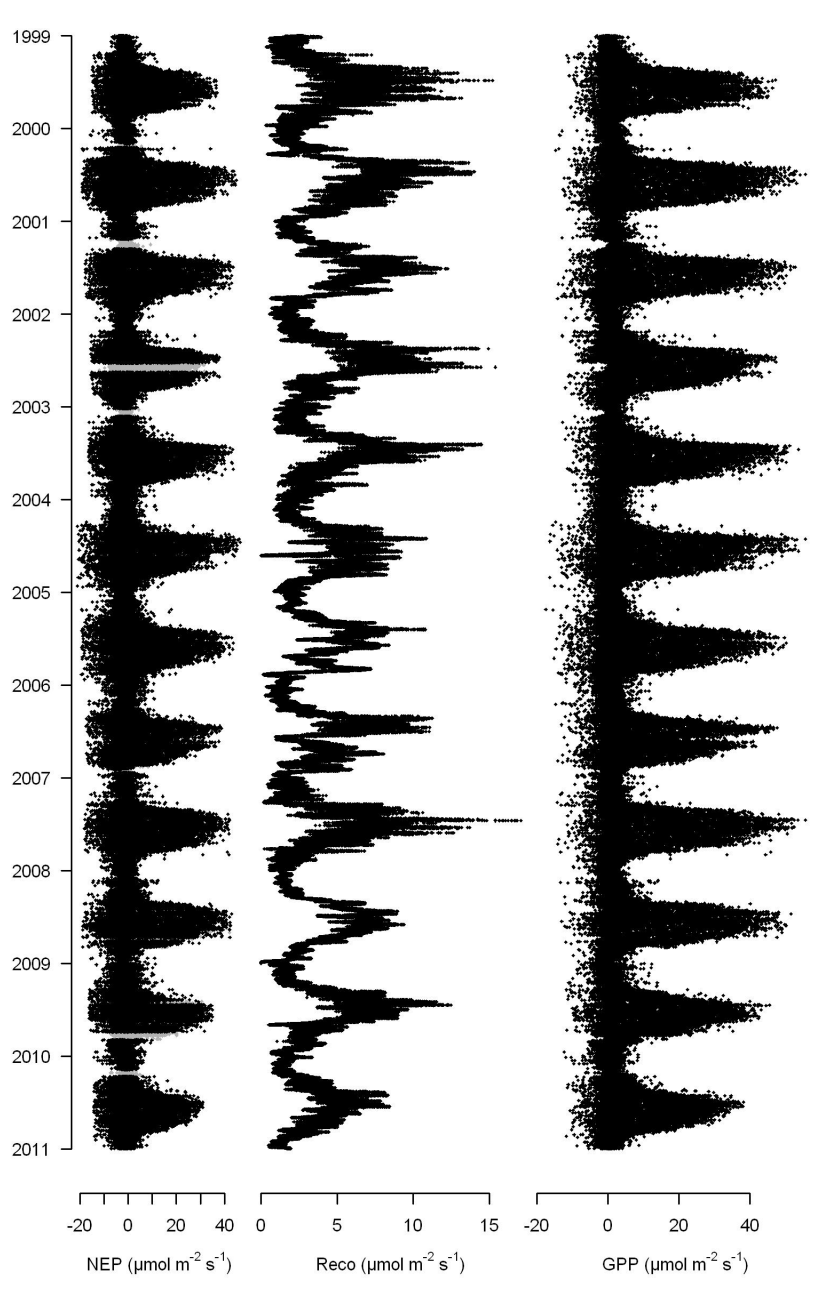

Fig. 2. Half-hourly average values of quality-controlled (black symbols) and gap-filled (gray symbols) NEP, $R_{\text {eco }}$ and GPP for the period 1999-2010, at the oak plantation, Straits Inclosure, Alice Holt Forest.

\subsection{Annual cycle of carbon fluxes}

Substantial seasonal and inter-annual variations in component fluxes were measured (Fig. 2). In order to describe the mean annual carbon cycle for each of these components, data from all $12 \mathrm{yr}$ were pooled (Fig. 3c). Over the winter period (December, January, February), GPP was close to zero and started to rise slowly from around day of year (DOY) 50 as a result of early bud break and leaf expansion of the shrub layer, exploiting available light. At approximately DOY 100 GPP started to rise more rapidly, coinciding with bud break and expansion of the tree canopy, peaking at around DOY 170, with a mean summer (June, July and August) value of $13.5 \mathrm{~g} \mathrm{C} \mathrm{m}^{-2} \mathrm{~d}^{-1}$. A reduction in GPP started around DOY 200 as mean solar radiation levels declined (Fig. 3a); this reduction accelerated around the beginning of October ( $\sim$ DOY 280 ), corresponding with the start of canopy senescence. 
(a)



(b)

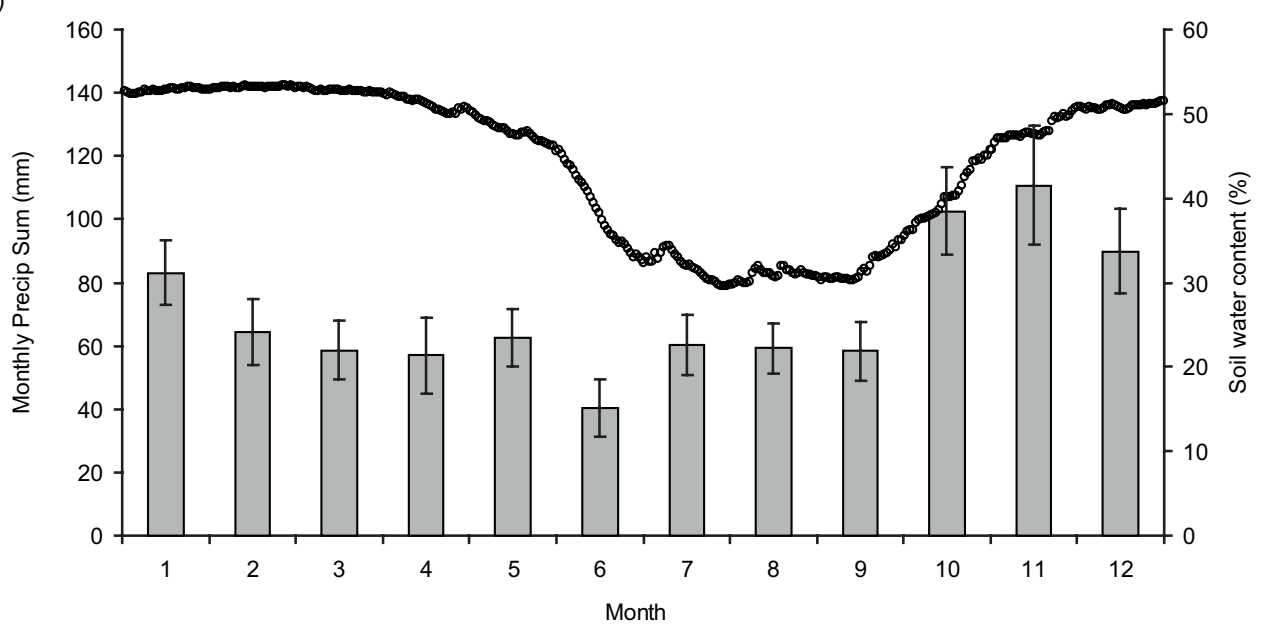

(c)

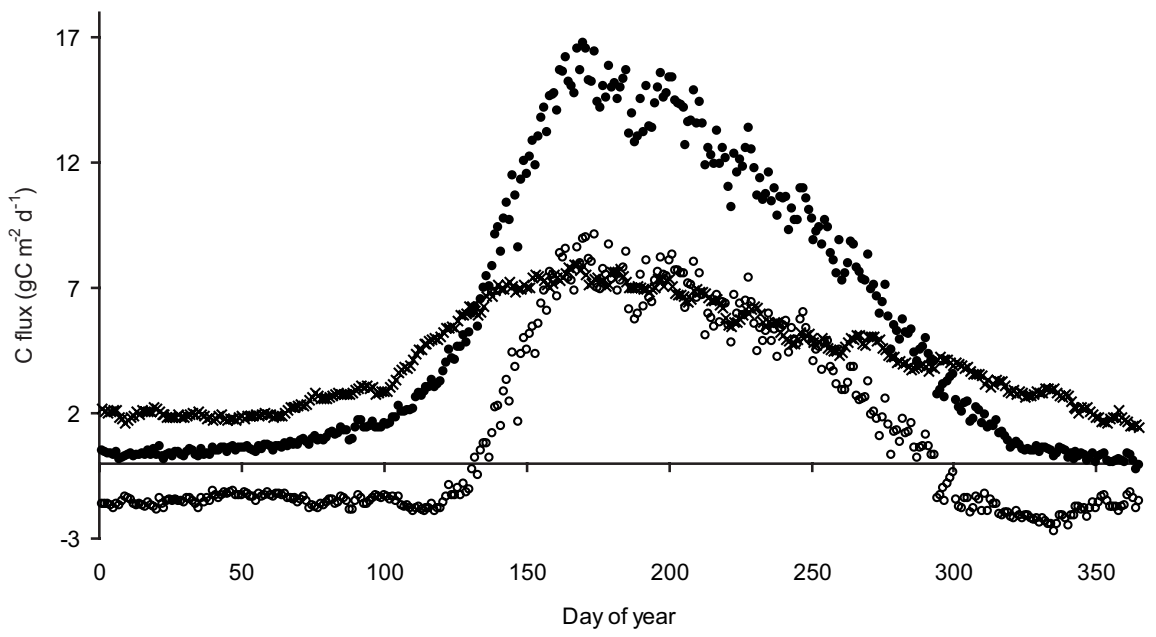

Fig. 3. Average annual cycle of key climatic variables and $\mathrm{CO}_{2}$ flux components between 1999-2010 for the oak plantation at the Straits Inclosure, Alice Holt Forest: (a) $T_{\max }$ (open symbols), $T_{\min }$ (closed symbols) and incident solar radiation (solid line); (b) mean monthly precipitation (error bars represent \pm 1 standard error, $n=12$ ) and volumetric soil water content recorded under grass nearby (open symbols); and (c) daily GPP (solid circles), $R_{\text {eco }}$ (crosses) and NEP (open circles). 


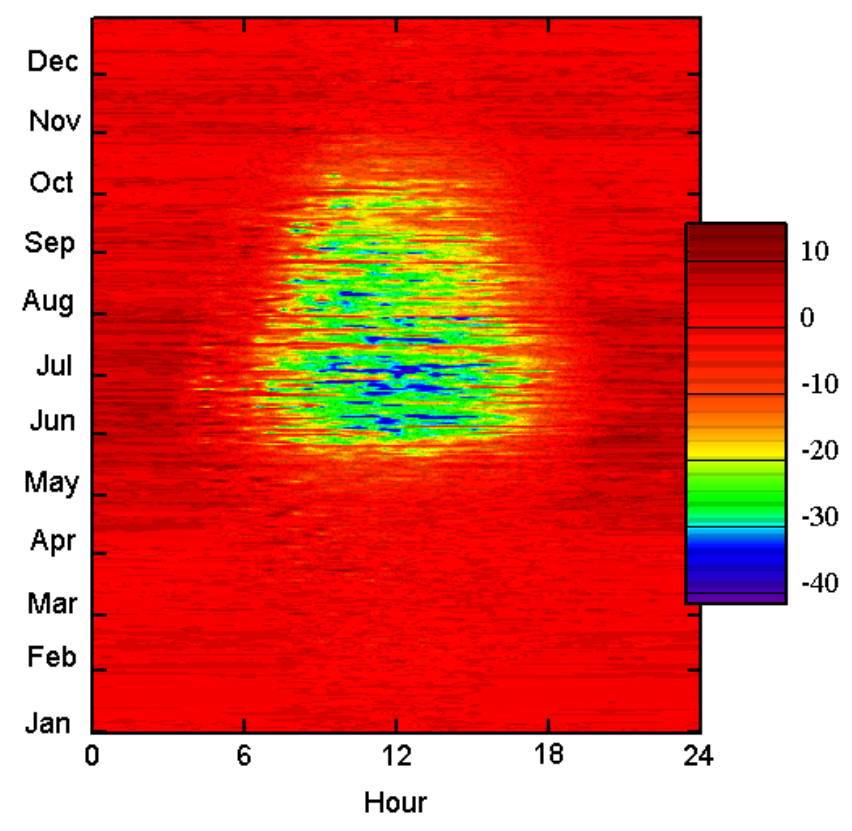

Fig. 4. A typical (2003) net ecosystem exchange (NEE) "fingerprint" plot showing diurnal (x-axis) and seasonal (y-axis) $\mathrm{CO}_{2}$ fluxes $\left(\mu \mathrm{mol} \mathrm{m}{ }^{-2} \mathrm{~s}^{-1}\right.$ ) for the oak plantation at the Straits Inclosure, Alice Holt Forest, generated by the CarboEurope on-line gap filling and partitioning tool.

$R_{\text {eco }}$ also demonstrated a strong seasonal cycle (Fig. 3c), with the lowest fluxes occurring over the cooler winter period at a mean rate $2.0 \mathrm{~g} \mathrm{C} \mathrm{m}^{-2} \mathrm{~d}^{-1}$. $R_{\text {eco }}$ stayed low until approximately DOY 70, when it began to increase slowly at first and more rapidly from DOY 100, coinciding with increases in air and soil temperature. The highest $R_{\text {eco }}$ occurred during the warm summer months between DOY 145 and 200, with a mean summer rate of $6.7 \mathrm{~g} \mathrm{C} \mathrm{m}^{-2} \mathrm{~d}^{-1}$. The NEP of an ecosystem is determined by the relative balance of GPP and $R_{\text {eco. }}$. In this study daily NEP remained negative until on average DOY 132; prior to this point small increases in GPP and $R_{\text {eco }}$ effectively cancel each other out, ensuring that NEP remains constant until approximately DOY 115 . During spring (DOY 115-150) as the increase in GPP exceeded losses through $R_{\text {eco }}$, daily NEP rapidly turned from being negative (a $\mathrm{CO}_{2}$ source) to positive (a $\mathrm{CO}_{2}$ sink); over the summer, high levels of GPP relative to $R_{\text {eco }}$ resulted in a mean NEP of $6.8 \mathrm{~g} \mathrm{C} \mathrm{m}^{-2} \mathrm{~d}^{-1}$. On a daily timescale the forest continued to act as a net $\mathrm{CO}_{2}$ sink until on average DOY 297, after which it reverted to being a source. Over the 12-yr measurement period, mean daily winter (December-February) NEP was $-1.6 \mathrm{~g} \mathrm{C} \mathrm{m}^{-2} \mathrm{~d}^{-1}$.

The diurnal and seasonal changes of NEE for a typical year (2003) are shown in the "finger print" plot (Fig. 4). Maximum $\mathrm{CO}_{2}$ sequestration occurred during spring and summer daylight hours (green through to dark blue). The asymmetrical shape of the NEE "pulse" within the year was caused by the rapid increase in net $\mathrm{CO}_{2}$ uptake in the spring followed

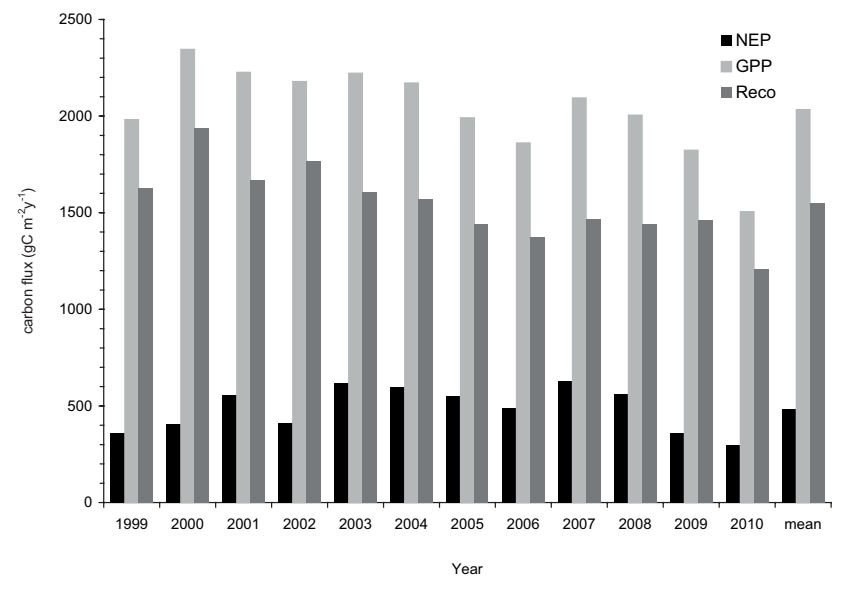

Fig. 5. Annual sum of NEP, GPP and $R_{\text {eco }}$ for the period 1999-2010 at the oak plantation, Straits Inclosure, Alice Holt Forest

by a more gradual decline at the end of the growing season. In addition, higher $\mathrm{CO}_{2}$ uptake fluxes are evident during the morning than in the afternoon during September, indicating the possibility of moisture stress.

\subsection{Inter-annual variation in NEP, GPP and $\boldsymbol{R}_{\text {eco }}$}

The carbon budget and partitioned fluxes were calculated for each year of the study period (Fig. 5 and Table 3). Annual NEP varied from $296 \mathrm{~g} \mathrm{C} \mathrm{m}^{-2} \mathrm{yr}^{-1}$ (2010) to a maximum of $629 \mathrm{~g} \mathrm{C} \mathrm{m}^{-2} \mathrm{yr}^{-1}$ (2007), with a 12-yr average of $486 \pm 73 \mathrm{~g} \mathrm{C} \mathrm{m}^{-2} \mathrm{yr}^{-1}$ (95\% CI). The maximum year-toyear variation in NEP was therefore $333 \mathrm{~g} \mathrm{C} \mathrm{m}^{-2} \mathrm{yr}^{-1}$. The growing season length (GSL), here defined as the number of days between the first and last day where the integrated 3-day NEP was positive (a net sink of carbon), also varied considerably from year to year (Table 4). The average GSL was 165 days, ( \pm 6 days, $95 \% \mathrm{CI}$ ); the longest GSL occurred in 2007 (186 days) and the shortest in 2005 (153 days).

The inter-annual variation in the calculated $R_{\text {eco }}$ was large (from a minimum of 1210 to a maximum of $1940 \mathrm{~g} \mathrm{C} \mathrm{m}^{-2} \mathrm{yr}^{-1}$, Table 3), and the standard deviation (SD) was larger than that for NEP (192 and $115 \mathrm{~g} \mathrm{C} \mathrm{m}^{-2} \mathrm{yr}^{-1}$, respectively, Table 3). Annual GPP ranged from $1506 \mathrm{~g} \mathrm{C} \mathrm{m}^{-2} \mathrm{yr}^{-1}$ (2010) to $2346 \mathrm{~g} \mathrm{C} \mathrm{m}^{-2} \mathrm{yr}^{-1}$ (2000), with $\mathrm{SD}=223 \mathrm{~g} \mathrm{C} \mathrm{m}^{-2} \mathrm{yr}^{-1}$. As $R_{\text {eco }}$ is driven in part by preceding GPP, it could be argued that the NEP budget for any given year should be calculated over the growing season year (i.e. 1 April through to 31 March in the following year). However, our results show that this approach had very little effect on the annual sums in most years, and only in 2005 was there a noticeable difference (Table 3).

Anomalies from the long-term monthly means in GPP, $R_{\text {eco }}$ and associated environmental variables were calculated (Fig. 6). GPP was high during the spring and summer of 2000 probably because of the combined effect of high peak LAI $\left(7.7 \mathrm{~m}^{2} \mathrm{~m}^{-2}\right)$ and average solar radiation receipts. GPP was 
Table 3. Annual values 1999-2010 of carbon flux components for the oak plantation at the Straits Inclosure in Alice Holt Forest. Radiationuse efficiency (RUE) is calculated as GPP/incident solar radiation. NEP $_{\text {gsy }}$ is the sum of NEP in the growing season year, i.e. 1 April through to 31 March in the following year. Peak LAI was back calculated from cumulative LAI measured using litterfall traps sampled bi-weekly.

\begin{tabular}{lrrrrrrrr}
\hline Year & $\begin{array}{r}\mathrm{NEP} \\
\mathrm{g} \mathrm{C} \mathrm{m}^{-2}\end{array}$ & $\begin{array}{r}R_{\mathrm{eco}} \\
\mathrm{g} \mathrm{C} \mathrm{m}^{-2}\end{array}$ & $\begin{array}{r}\mathrm{GPP} \\
\mathrm{g} \mathrm{C} \mathrm{m}^{-2}\end{array}$ & $R_{\mathrm{eco}} / \mathrm{GPP}$ & $\mathrm{NEP} / \mathrm{GPP}$ & $\begin{array}{r}\mathrm{RUE} \\
\mathrm{gC} \mathrm{MJ}^{-1}\end{array}$ & $\begin{array}{r}\mathrm{NEP}_{\mathrm{gsy}} \\
\mathrm{g} \mathrm{C} \mathrm{m}^{-2}\end{array}$ & $\begin{array}{r}\text { Peak LAI } \\
\mathrm{m}^{2} \mathrm{~m}^{-2}\end{array}$ \\
\hline 1999 & 357 & 1625 & 1983 & 0.820 & 0.180 & 0.486 & 345 & 6.49 \\
2000 & 406 & 1940 & 2346 & 0.827 & 0.173 & 0.616 & 405 & 7.72 \\
2001 & 557 & 1670 & 2227 & 0.750 & 0.250 & 0.575 & 538 & 6.94 \\
2002 & 412 & 1767 & 2180 & 0.811 & 0.189 & 0.554 & 426 & 5.52 \\
2003 & 617 & 1606 & 2223 & 0.722 & 0.278 & 0.542 & 613 & 6.17 \\
2004 & 600 & 1573 & 2172 & 0.724 & 0.276 & 0.563 & 585 & 6.55 \\
2005 & 551 & 1441 & 1992 & 0.723 & 0.277 & 0.510 & 630 & 4.97 \\
2006 & 488 & 1374 & 1862 & 0.738 & 0.262 & 0.464 & 466 & 5.42 \\
2007 & 629 & 1466 & 2094 & 0.700 & 0.300 & 0.529 & 664 & 6.47 \\
2008 & 563 & 1442 & 2006 & 0.719 & 0.281 & 0.520 & 518 & 6.21 \\
2009 & 359 & 1465 & 1824 & 0.803 & 0.197 & 0.458 & 367 & 4.4 \\
2010 & 296 & 1210 & 1506 & 0.804 & 0.196 & 0.414 & 321 & 4.18 \\
Mean & 486 & 1548 & 2034 & 0.762 & 0.239 & 0.520 & 490 & 5.92 \\
SEM & 33.3 & 55.6 & 65.8 & 0.01 & 0.01 & 0.02 & 34.0 & 0.32 \\
SD & 115 & 192 & 223 & 0.01 & 0.05 & 0.04 & 117.67 & 1.05 \\
\hline
\end{tabular}

$* \mathrm{SEM}=$ standard error of the mean

Table 4. Onset of growing season (OGS), end of growing season (EGS) and growing season length (GSL) defined by the start and end of net $\mathrm{CO}_{2}$ uptake, at the Straits Inclosure, Alice Holt Forest.

\begin{tabular}{lrrr}
\hline Year & OGS (DOY) & EGS (DOY) & GSL (days) \\
\hline 1999 & 132 & 297 & 165 \\
2000 & 135 & 291 & 156 \\
2001 & 132 & 303 & 171 \\
2002 & 135 & 291 & 156 \\
2003 & 126 & 300 & 174 \\
2004 & 132 & 291 & 159 \\
2005 & 141 & 294 & 153 \\
2006 & 138 & 312 & 174 \\
2007 & 117 & 303 & 186 \\
2008 & 129 & 297 & 168 \\
2009 & 129 & 285 & 156 \\
2010 & 132 & 297 & 165 \\
Mean & 132 & 297 & 165 \\
SEM & 1.8 & 2.1 & 2.8 \\
SD & 6.1 & 7.2 & 9.9 \\
\hline
\end{tabular}

not adversely affected by the major Europe-wide drought year in 2003, and the year had the second highest GPP sum over the entire 12-yr period probably because of the aboveaverage solar radiation levels. Although 2003 had the lowest precipitation total, this followed a wet end to 2002 (Fig. 6a) and soil moisture (Fig. 6c) did not start to decline below the long-term monthly mean until July. Precipitation was also lower than average for most of 2005; although summer soil moisture levels did not fall as low as in 2003, the decline started a month earlier in the year, which combined with the lower levels of solar radiation caused a reduction in summer GPP in 2005 . It is likely that low $R_{\text {eco }}$ values in late summer/early autumn, as occurred in 2003, 2005 and 2006, can be attributed to low soil moisture levels (Fig. 6c).

GPP was low in 2009 and 2010 because of considerable damage to the forest canopy following a major outbreak of defoliating moth caterpillars, mostly Tortrix viridana $\mathrm{L}$., but also Operophtera brumata L., early in the year (Pitman et al., 2010). This was despite an increase in incident solar radiation of $4 \%$ in 2009 and $7 \%$ in 2010 received during the May to July period of each year. The infestation caused a reduction in peak LAI values (Table 3 ) from the longterm mean of $26 \%$ in $2009\left(4.40 \mathrm{~m}^{2} \mathrm{~m}^{-2}\right)$ and $30 \%$ in 2010 $\left(4.18 \mathrm{~m}^{2} \mathrm{~m}^{-2}\right)$, which resulted in a reduction of GPP by $5 \%$ in 2009 and $33 \%$ in 2010.

The overall time trends in annual GPP, $R_{\text {eco }}$ and NEP were tested by linear regression against year. Although there was no apparent long-term trend in the annual NEP $(p=0.89)$, this resulted from similar significant decreases in both GPP $\left(-46.1 \mathrm{~g} \mathrm{C} \mathrm{m}^{-2} \mathrm{yr}^{-1}\right.$, standard error (s.e.) 13.7, $\left.p<0.01\right)$ and $R_{\text {eco }}\left(-44.7 \mathrm{~g} \mathrm{C} \mathrm{m}^{-2} \mathrm{yr}^{-1}\right.$, s.e. 9.2, $\left.p<0.001\right)$ over time. If the last two annual values from the insect-affected years of 2009 and 2010 were omitted, there was a significant positive trend in NEP $\left(+21.0 \mathrm{~g} \mathrm{C} \mathrm{m}^{-2} \mathrm{yr}^{-1}\right.$, s.e. 8.5 , $p<0.05$ ), because the declining trend in GPP was reduced to $-24.2 \mathrm{~g} \mathrm{C} \mathrm{m}^{-2} \mathrm{yr}^{-1}$, although the declining trend in $R_{\text {eco }}$ was not affected $\left(-45.2 \mathrm{~g} \mathrm{C} \mathrm{m}^{-2} \mathrm{yr}^{-1}\right.$, s.e. 12.2, $\left.p<0.01\right)$. However, none of these changes in slope when 2009 and 2010 values were omitted were significant because of their large standard errors. 

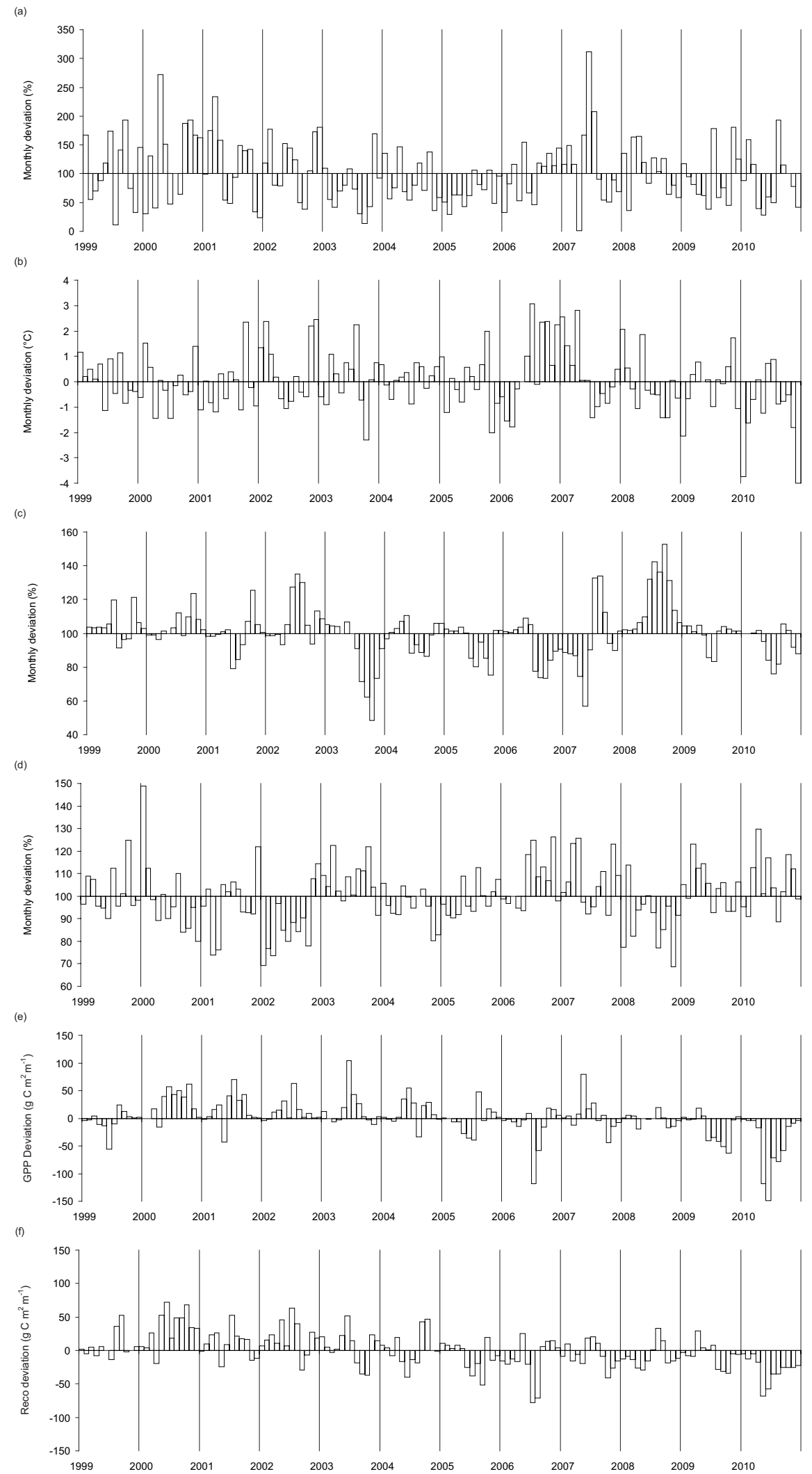

Fig. 6. Deviation from the 12-yr monthly average (1999-2010) for key climatic variables and partitioned $\mathrm{CO}_{2}$ flux components at the oak plantation woodland, Straits Inclosure, Alice Holt Forest: (a) precipitation, (b) air temperature, (c) soil moisture, (d) solar radiation, (e) GPP and (f) $R_{\text {eco }}$. 


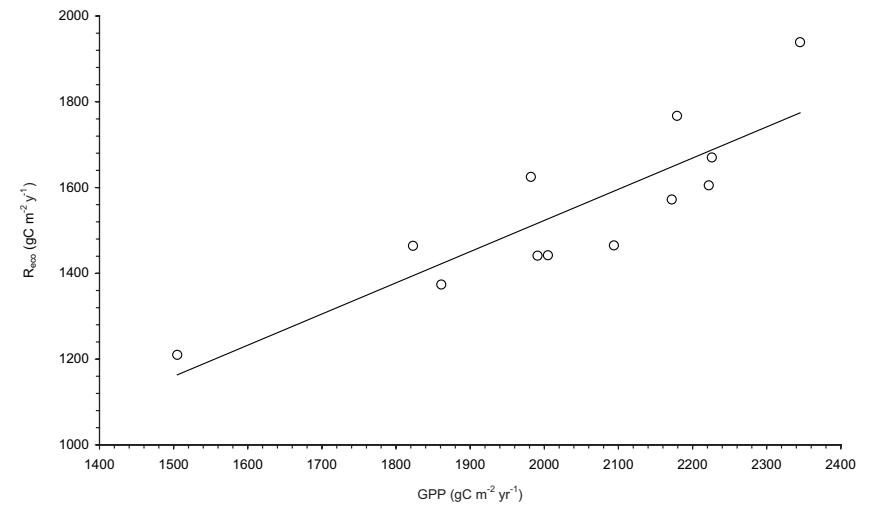

Fig. 7. Relationship between annual $R_{\text {eco }}$ and annual GPP $\left(r^{2}=0.74, p<0.001\right)$.

\subsection{Environmental controls of GPP, $R_{\text {eco }}$ and NEP}

NEP is the relatively small difference between the two much larger fluxes of GPP and $R_{\text {eco }}$ (Baldocchi, 2008), which were shown to be tightly correlated (Fig. 7 and Table 3), with a mean $R_{\text {eco }} / \mathrm{GPP}$ ratio of 0.76 ( $\left.\pm 0.03 \mathrm{CI}\right)$. Therefore, in order to understand the possible causes of inter-annual variation in NEP, it is necessary to explore the causes of variation in GPP and $R_{\text {eco. }}$.

On an annual time scale, GPP was weakly correlated with mean annual air temperature $\left(r^{2}=0.27, p<0.1\right)$ but not with growing season incident solar radiation $\left(r^{2}=0.13\right.$, $p>0.1)$ or GSL $\left(r^{2}<0.1, p>0.1\right)$ (data not shown). Therefore radiation use efficiency (RUE $=\mathrm{GPP} /$ incident solar radiation) varied between years (mean $=0.52 \mathrm{~g} \mathrm{C} \mathrm{MJ}^{-1}$, $12 \% \mathrm{CV}$, Table 3). There was a stronger correlation between GPP and intercepted solar radiation $\left(S_{\mathrm{g}}{ }^{\mathrm{i}}, r^{2}=0.46\right.$, $p<0.05$, Fig. 8a) resulting in less interannual variation in radiation use efficiency calculated on an intercepted basis $\left(\right.$ mean $\left.=0.88 \mathrm{~g} \mathrm{C} \mathrm{MJ}^{-1}, 8.5 \% \mathrm{CV}\right)$. The strongest correlation was between annual GPP and peak LAI $\left(r^{2}=0.70\right.$, $p<0.001$, Fig. 8b). Peak LAI showed a significant linear decline over time $\left(-0.208 \mathrm{LAI} \mathrm{yr}^{-1}, r^{2}=0.51, p<0.01\right)$, and this resulted in reduced fractional radiation interception and reduced annual GPP and $R_{\text {eco }}$ over time. Resulting seasonal differences in RUE for years of contrasting LAI are illustrated in Fig. 9 . The year with highest observed LAI, 2000, had a higher than average RUE during the June-October period; conversely, 2009 with low LAI showed a below average RUE.

Coefficients of an exponential function were derived by fitting monthly $R_{\text {eco }}$ and mean monthly air temperature (Table 5). The high overall degree of correlation (mean $r^{2}=0.82$ ) within each year is not surprising given the method by which $R_{\text {eco }}$ was estimated (see Sect. 2.5). However, this approach is useful in highlighting the variation in response between years. Figure 10 shows the relationship for years of contrasting $R_{\text {eco }}$, i.e. high (2000 and 2002) and
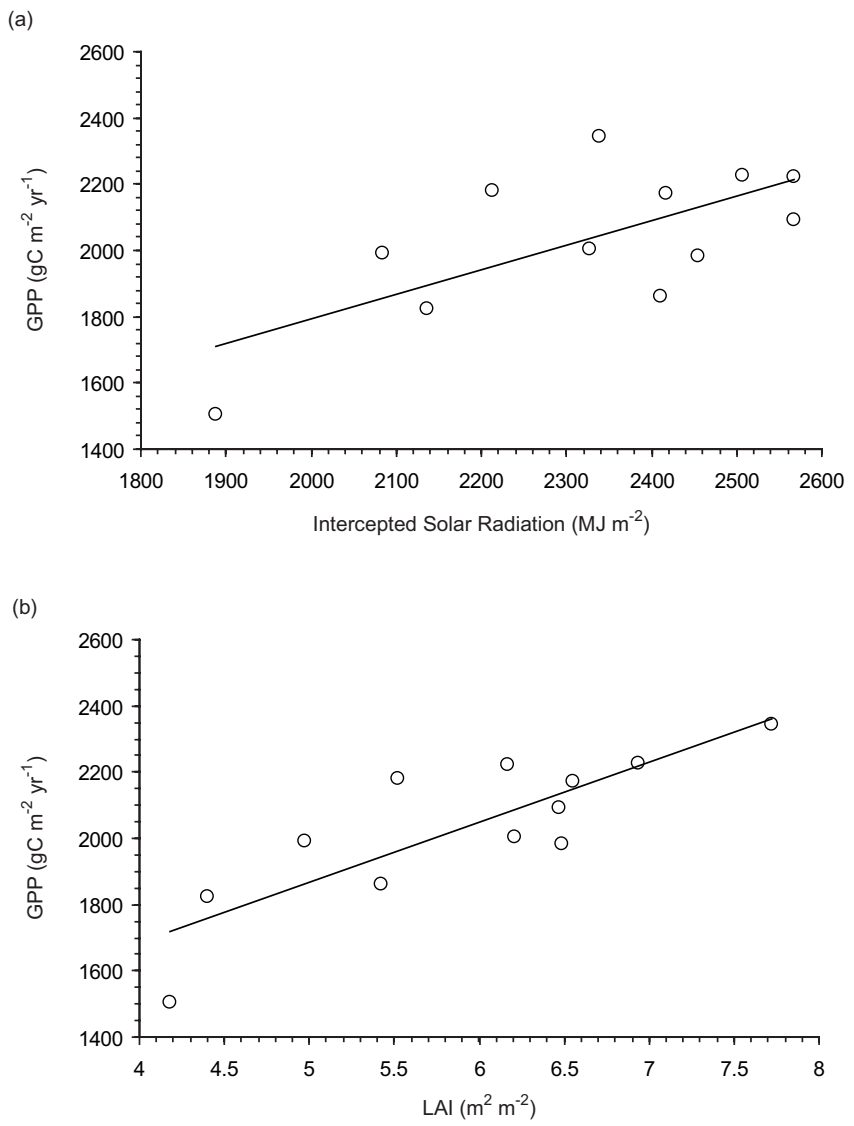

Fig. 8. Relationship between (a) annual GPP and intercepted solar radiation $\left(r^{2}=0.46, p<0.05\right)$ and (b) annual GPP and peak LAI $\left(r^{2}=0.7, p<0.001\right)$.

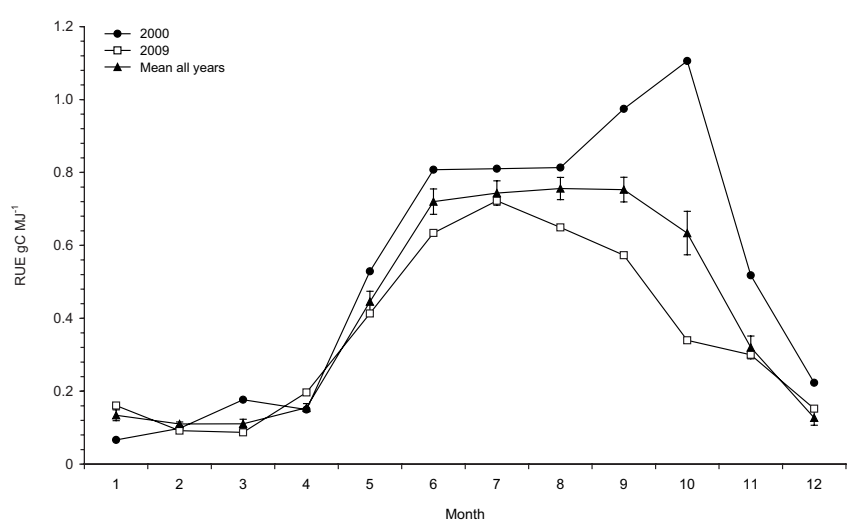

Fig. 9. Monthly RUE for contrasting years of high GPP (2000) and low GPP (2009).

low (2006 and 2010). It is evident that the years of high annual $R_{\text {eco }}$ showed an enhanced sensitivity of monthly $R_{\text {eco }}$ to temperature and, conversely, a lower sensitivity during the years of low annual $R_{\text {eco }}$. When the monthly $R_{\text {eco }}$ values are separated between growing season (May-October, inclusive) and non-growing season months, it becomes clear 
Table 5. Coefficients of an exponential model-fitted monthly $R_{\text {eco }}$ to mean monthly air temperature, calculated mean Q10 values and $r^{2}$ values for the Straits Inclosure, Alice Holt Forest. $r^{2}$ values are also shown for exponential regressions for the non-growing (November-March) and growing (April-October) season months, separately.

\begin{tabular}{lrrrrrr}
\hline Year & Intercept & $e$ & $r^{2}$ & Q10 & $\begin{array}{r}\text { Non-growing } \\
\text { season } r^{2}\end{array}$ & $\begin{array}{r}\text { Growing } \\
\text { season } r^{2}\end{array}$ \\
\hline 1999 & 36.12 & 0.114 & 0.895 & 3.13 & 0.973 & 0.537 \\
2000 & 41.89 & 0.119 & 0.815 & 3.30 & 0.469 & 0.110 \\
2001 & 40.80 & 0.108 & 0.881 & 2.95 & 0.936 & 0.571 \\
2002 & 35.04 & 0.122 & 0.740 & 3.38 & 0.878 & 0.242 \\
2003 & 49.51 & 0.084 & 0.688 & 2.32 & 0.692 & 0.319 \\
2004 & 41.25 & 0.100 & 0.836 & 2.73 & 0.925 & 0.001 \\
2005 & 47.66 & 0.081 & 0.719 & 2.26 & 0.864 & 0.009 \\
2006 & 38.69 & 0.086 & 0.655 & 2.37 & 0.751 & 0.200 \\
2007 & 19.79 & 0.155 & 0.924 & 4.72 & 0.525 & 0.739 \\
2008 & 24.77 & 0.139 & 0.948 & 4.01 & 0.676 & 0.969 \\
2009 & 36.88 & 0.103 & 0.777 & 2.81 & 0.801 & 0.207 \\
2010 & 39.90 & 0.088 & 0.934 & 2.41 & 0.765 & 0.768 \\
Mean & 38.22 & 0.107 & 0.818 & 3.00 & 0.771 & 0.389 \\
SEM & 2.53 & 0.01 & - & 0.22 & - & - \\
SD & 8.77 & 0.62 & - & 0.78 & - & - \\
\hline
\end{tabular}

that the relationship with temperature is much more consistent in the non-growing season (Table 5). In several years there is no evident relationship between growing season $R_{\text {eco }}$ and temperature, suggesting that other factors are more influential, accounting for the reduction in sensitivity to temperature shown in Fig. 10. This sensitivity when quantified as the apparent Q10 value was found to be strongly related to the mean summer (July-September) soil moisture content (Fig. 11, $\left.y=0.099 x-0.06 ; r^{2}=0.78\right)$. This analysis indicates that high rates of $R_{\text {eco }}$ occur at this site under the combined conditions of high air and soil temperature and higher than average summer soil moisture.

As noted above, annual NEP did not show any clear trends over time. While annual NEP sums were related to neither the single variables of annual incident radiation $\left(S_{\mathrm{g}}\right)$, precipitation $(P)$, average air temperature, mean summer soil moisture content (SM) nor peak leaf area index, NEP was weakly related to intercepted radiation, $S_{\mathrm{g}}{ }^{\mathrm{i}}\left(r^{2}=0.421, p<0.05\right)$. When possible drivers were analysed with multiple regression, the best linear model derived was NEP $\propto S_{\mathrm{g}}{ }^{\mathrm{i}}+P+\mathrm{SM}$ $\left(r^{2}=0.715, p=0.014\right)$, accounting for more than $70 \%$ of the variation in NEP.

\subsection{NEP comparison with biometric-based estimates}

Regular tree mensuration assessments have been carried out as part of the ECN vegetation monitoring protocol (Sykes and Lane, 1996) in plots within the potential EC (eddy covariance) footprint (Table 1), therefore enabling a comparison with the EC-based estimates of NEP. The mensuration data were used to estimate stem volumes and above-ground biomass, using empirical biometric relation-

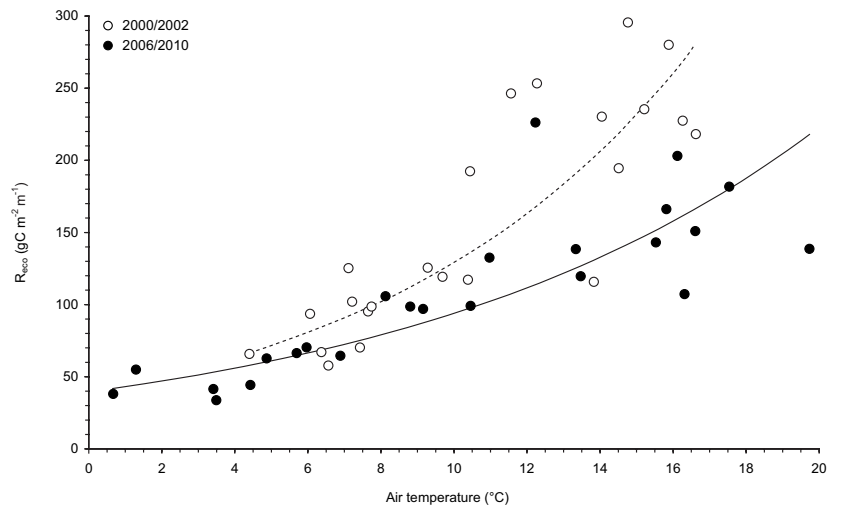

Fig. 10. Relationship between the monthly sum of $R_{\text {eco }}$ and mean monthly air temperature for years of high (2000 and 2002; $\left.r^{2}=0.75\right)$ and low $\left(2006\right.$ and $\left.2010 ; r^{2}=0.78\right)$ annual $R_{\text {eco }}$.

ships derived from sets of 10 oak trees harvested and weighed in the inclosure in both 2005 and in 2009. Assuming a $\mathrm{C}$ content of dry weight of $50 \%$ (Broadmeadow and Matthews, 2003) gives a mean annual estimated increase between 1997 and 2011 in above-ground biomass of $260 \mathrm{~g} \mathrm{C} \mathrm{m}^{-2} \mathrm{yr}^{-1}$ (canopy trees only). Using relationships found by McKay et al. (2003) specifically for oak trees, the below-ground biomass increment was estimated as $87 \mathrm{~g} \mathrm{C} \mathrm{m}^{-2} \mathrm{yr}^{-1}$. Thus the mean annual (biometric) estimated $\mathrm{C}$ uptake was $347 \mathrm{~g} \mathrm{C} \mathrm{m}^{-2} \mathrm{yr}^{-1}, 71 \%$ of the mean NEP estimated from EC fluxes $\left(486 \mathrm{~g} \mathrm{C} \mathrm{m}^{-2} \mathrm{yr}^{-1}\right)$.

\section{Discussion}

\subsection{Annual $\mathrm{C}$ budget of woodlands in Britain and Ireland}

Using eddy covariance (EC) measurements we have provided a 12-yr time series of partitioned forest $\mathrm{CO}_{2}$ fluxes and quantified the inter-annual variation of these partitioned fluxes (Fig. 5) for a managed oak woodland in south-eastern England, revealing important differences in their seasonal phase and amplitude (Fig. 3c). Although the accuracy of eddy covariance measurements in establishing $\mathrm{C}$ balances has been questioned because of the problems of filling inevitable data gaps, the various methodological corrections required, difficulties in measuring nighttime fluxes, and advection problems, some comparisons have shown good agreement with direct measurements of changes in C stocks (Gough et al., 2008; Thomas et al., 2011). Whilst we do not have the detailed representative component stock change estimates, as in the exemplary work by Butt et al. (2009) or Gough et al. (2008), the available mensuration data suggest NEP values that are similar, but $29 \%$ lower than those estimated by eddy covariance (EC). However, this biometric estimate includes neither the substantial $\mathrm{C}$ uptake by the woody understorey, which might be $\sim 10 \%$ (Moore et al., 2007), nor any 


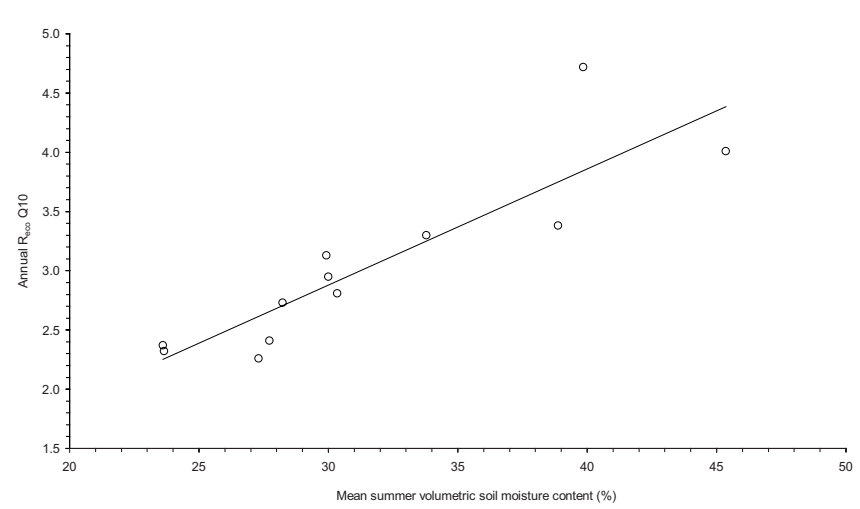

Fig. 11. Relationship between annual $R_{\text {eco }}$ Q10 and summer volumetric soil moisture content measured at a depth of $10 \mathrm{~cm}$ at the Alice Holt Research Station $\left(r^{2}=0.78, p<0.001\right)$. Annual Q10 values were calculated from the coefficients of an exponential function fitted to monthly $R_{\text {eco }}$ and mean monthly air temperature.

increase in soil organic $\mathrm{C}$ content, estimated in this woodland to be $34 \mathrm{~g} \mathrm{C} \mathrm{m}^{-2} \mathrm{yr}^{-1}$ (Benham et al., 2012), about $7 \%$ of EC NEP. If these components are included, agreement to within 10-15\% gives some confidence in the NEP values derived from EC data, given the low precision of the biometric approach.

Between 1999 and 2010, the forest acted as a substantial net $\mathrm{C}$ sink with a mean NEP of $486 \mathrm{~g} \mathrm{C} \mathrm{m}^{-2} \mathrm{yr}^{-1}$, further evidence that temperate deciduous woodlands actively contribute to the global terrestrial C sink (Luyssaert et al., 2007). Furthermore, the results from this study provide a good basis for understanding the processes of $\mathrm{CO}_{2}$ exchange within deciduous woodlands under British conditions, which to date have been poorly characterised. Despite the fact that there are more than 30 forest EC flux sites (Clement et al., 2012) currently active across Europe, Britain has only a few, of which only two can be considered long-term studies, (i.e. $>5 \mathrm{yr}$ ): this Alice Holt site, and the Griffin Forest site in central Scotland, located in a Sitka spruce (Picea sitchensis (Bong.) Carr.) plantation, established in 1997 (Clement et al., 2012). Between 1997 and 2001, average NEP of that young coniferous forest was $721 \mathrm{~g} \mathrm{C} \mathrm{m}^{-2} \mathrm{yr}^{-1}$, which is substantially larger $(+48 \%)$ than the NEP observed in the current study. Whilst partitioned flux estimates from Griffin Forest indicate very similar levels of $R_{\text {eco }}\left(1533 \mathrm{~g} \mathrm{C} \mathrm{m}^{-2} \mathrm{yr}^{-1}\right)$ to the current study $\left(1548 \mathrm{~g} \mathrm{C} \mathrm{m}^{-2} \mathrm{yr}^{-1}\right)$, despite differing soil types, the longer growing season and higher carbon use efficiency of coniferous forests meant that GPP at Griffin was substantially higher $(+11 \%)$. Under milder conditions than those experienced at the Griffin Forest site, the NEP of Sitka spruce in Dooary, central Ireland, has been shown to be even higher (830-890 $\mathrm{g} \mathrm{C} \mathrm{m}^{-2} \mathrm{yr}^{-1}$; Black et al., 2007).

Although the mean NEP reported here is at the high end of the range reported from other comparable temperate deciduous or semi-deciduous woodlands (Table 6), it is not the highest and has been exceeded at other European deciduous sites. NEP of $660 \mathrm{~g} \mathrm{C} \mathrm{m}^{-2} \mathrm{yr}^{-1}$ was reported at the Collelongo Forest site in Italy (Valentini et al., 2000) and NEP of $550 \mathrm{~g} \mathrm{C} \mathrm{m}^{-2} \mathrm{yr}^{-1}$ from an oak sub plot at the Kannenbruch Forest in Germany (Kutsch et al., 2005). However, it should be noted that both of these values were derived from much shorter time series than this study, and in half the $12 \mathrm{yr}$ at Alice Holt the NEP was between 550 and $650 \mathrm{~g} \mathrm{C} \mathrm{m}^{-2} \mathrm{yr}^{-1}$ (Table 3).

A site where comparable EC flux measurements have been made in deciduous woodland is that at Wytham Woods in Oxfordshire (Thomas et al., 2011), where a relatively short-term study showed very similar rates of GPP to this study $\left(2110 \mathrm{~g} \mathrm{C} \mathrm{m}^{-2} \mathrm{yr}^{-1}\right)$. It is noteworthy that the Straits site shows one of the larger mean annual GPP values in any of the long-term temperate or boreal forests so far reported (see Table 6). Only the two evergreen conifer plantations at Griffin and Dooary have higher GPP values. However, substantially higher $R_{\text {eco }}$ rates at Wytham Woods $\left(1980 \mathrm{~g} \mathrm{C} \mathrm{m}^{-2} \mathrm{yr}^{-1}\right)$ resulted in a much lower mean annual NEP $\left(130 \mathrm{~g} \mathrm{C} \mathrm{m}^{-2} \mathrm{yr}^{-1}\right)$. The Straits Inclosure and Wytham Woods have had contrasting histories; whereas our study site has been managed as commercial forest, with regular interventions, it is likely that the higher levels of $R_{\text {eco }}$ observed at Wytham Woods are a result of less intensive management over the last few decades (Kirby, 2010), resulting in greater levels of decomposing deadwood and possibly higher level of heterotrophic respiration due to enhanced soil activity and C levels.

No trend in NEP was observed at our site over the $12 \mathrm{yr}$, although there were declining trends in both GPP and $R_{\text {eco. }}$. Recent data for 2011 are consistent with these trends. This contrasts with the observed increasing NEP trend of $23 \mathrm{~g} \mathrm{C} \mathrm{m}^{-2} \mathrm{yr}^{-1}$ observed over $14 \mathrm{yr}$ in a similarly aged beech stand in Denmark, attributed to increasing GPP (Pilegaard et al., 2011).

\subsection{Inter-annual variation in NEP, GPP and $R_{\text {eco }}$}

Understanding of the sources of inter-annual variation in NEP, GPP and $R_{\text {eco }}$ within forest ecosystems is improving as the number of EC forest sites where multi-year records are available increases. In this study, the 12-yr measurement period showed quite high inter-annual variations in NEP, GPP and $R_{\text {eco }}$ (SD of 115,223 and $192 \mathrm{~g} \mathrm{C} \mathrm{m}^{-2} \mathrm{yr}^{-1}$ respectively). This may be because of the influence of the variable temperate oceanic climate, but it may also be because the length of record means that there is an increased likelihood of including anomalous or extreme climate years and episodes of biotic stresses such as pests and diseases. Although the variation in GPP and $R_{\text {eco }}$ is large compared to similar sites across a range of forest types (Table 6), the close linkage between $R_{\text {eco }}$ and GPP resulted in smaller variation in NEP, similar to that found at other sites (Table 6).

Within temperate forests a number of biotic and abiotic factors have been shown to have a controlling effect on GPP, 
Table 6. Published multi-annual values of NEP, GPP and $R_{\mathrm{eco}}$ for a range of temperate and boreal forest ecosystems

\begin{tabular}{|c|c|c|c|c|c|c|c|c|}
\hline Site & Country & $\begin{array}{l}\text { No of } \\
\text { years }\end{array}$ & $\begin{array}{r}\text { Measurement } \\
\text { period }\end{array}$ & $\mathrm{gC} \mathrm{m}^{-2} \mathrm{yr}^{-1}$ & $\begin{array}{r}\mathrm{GPP} \\
\mathrm{gC} \mathrm{m}^{-2} \mathrm{yr}^{-1}\end{array}$ & $\mathrm{gC} \mathrm{m}^{-2} \mathrm{yr}^{-1}$ & Forest Type & Authors \\
\hline Alice Holt & UK & 12 & 1999-2010 & $486(115)$ & $2034(228)$ & $1548(192)$ & $\begin{array}{l}\text { Temperate deciduous } \\
\text { oak plantation }\end{array}$ & Present study \\
\hline Griffin & UK & 5 & 1997-2001 & $721(60)$ & $2253(83)$ & $1533(37)$ & $\begin{array}{l}\text { Temperate conifer } \\
\text { plantation }\end{array}$ & Clement et al. (2012) \\
\hline De Inslag & Belgium & 6 & 1997-2002 & $-91(\mathrm{na})$ & 1234 (na) & 1326 (na) & Mixed temperate & Carrara et al. (2003) \\
\hline Lille Bøgeshov & Denmark & 14 & 1996-2009 & $156(103)$ & $1727(136)$ & $1570(97)$ & Temperate beech & Pilegaard et al. (2011) \\
\hline SMEAR II & Finland & 10 & 1999-2007 & $206(38)$ & $1031(54)$ & $825(39)$ & Boreal Scots pine & Ilvesniemi et al. (2009) \\
\hline Hesse & France & 10 & 1995-2005 & $386(171)$ & $1397(192)$ & $1011(138)$ & Temperate beech & Granier et al. (2008) \\
\hline Puéchabon & France & $6^{\mathrm{b}}$ & 2001-2006 & $278(117)$ & $1317(151)$ & $1018(68)$ & $\begin{array}{l}\text { Evergreen Mediterranean } \\
\text { forest }\end{array}$ & Allard et al. (2008) \\
\hline Dooary & Ireland & 8 & $2000-2006^{c}$ & $886(20)$ & $2311(145)$ & $1445(133)$ & $\begin{array}{l}\text { Temperate conifer } \\
\text { plantation }\end{array}$ & Saunders et al. (2012) \\
\hline Borden Forest & Canada & 8 & 1996-2003 & $141(112)$ & $1118(92)$ & $976(67)$ & $\begin{array}{l}\text { Mixed hardwood and } \\
\text { conifer }\end{array}$ & Teklemariam et al. (2009) \\
\hline $\begin{array}{l}\text { Northern Old } \\
\text { Black Spruce }\end{array}$ & Canada & 10 & 1994-2004 & $1.8(41)$ & $706(57)$ & $713(79)$ & Black spruce/veneer bog & Dunn et al. (2007) \\
\hline Harvard Forest & USA & 9 & $1993-2000$ & $201(36)$ & $1297(99)$ & $1099(91)$ & Mixed deciduous & Barford et al. (2001) \\
\hline Harvard Forest $\mathrm{t}^{\mathrm{a}}$ & USA & 13 & 1992-2004 & $245(100)$ & $1400(164)$ & $1153(105)$ & Mixed deciduous & Urbanski et al. (2007) \\
\hline Akou & Japan & 3 & $2001-2003$ & 615 (189) & $1759(220)$ & $1144(135)$ & $\begin{array}{l}\text { Warm temperate evergreen } \\
\text { broad-leaved }\end{array}$ & Kosugi et al. (2005) \\
\hline Takayama & Japan & 9 & 1994-2002 & $237(92)$ & $978(120)$ & $742(36)$ & $\begin{array}{l}\text { Cool temperate } \\
\text { deciduous forest }\end{array}$ & Saigusa et al. (2005) \\
\hline $\begin{array}{l}\text { Tomakomai } \\
\text { National Forest }\end{array}$ & Japan & 3 & 2001-2003 & $212(44)$ & $1673(60)$ & $1461(43)$ & Larch plantation & Hirata et al. (2007) \\
\hline
\end{tabular}

Where NEP data were not available, NEE has been used; figures in brackets are standard deviation;

a based on ecological year;

$\mathrm{b}$ of this 9-yr study, only 6 full years of data were available;

$\mathrm{c}$ based on the pre-thinning period.

including light interception, seasonal phenological development, temperature and moisture availability (Reichstein et al., 2007). The ratio of $\mathrm{CO}_{2}$ uptake to available light is a key variable, and has been shown to be influenced by a variety of environmental conditions and stresses including stand age, species composition, soil fertility, nutrient status (Gower et al., 1999) and the ratio of diffuse to total incident radiation (Jenkins et al., 2007; Alton, 2008). Here, the annual mean RUE varied between 0.62 and $0.41 \mathrm{~g} \mathrm{C} \mathrm{MJ}^{-1}$ incident radiation (2000 and 2010 respectively; Table 3), averaging $0.52 \mathrm{~g} \mathrm{C} \mathrm{MJ}^{-1}$. A comparison with other sites is made difficult as there is no common definition of RUE. Some studies have used net primary productivity as the numerator; others have used GPP (Schwalm et al., 2006). In years with low peak LAI, monthly RUE values were low (Fig. 9), particularly later in the year. It is unlikely that, over such monthly periods, variation in the ratio of diffuse to total incident radiation was a major contributor to this effect. Peak LAI explained a large proportion of the inter-annual variation in annual GPP $\left(r^{2}=0.7\right.$; Fig. 8$)$ because of its direct relationship with light interception and canopy photosynthesis; a similar response to that shown by Longdoz et al. (2010) across a range of forest sites in France. Furthermore, the trend of declining peak LAI over time at this site led to parallel declines in GPP and $R_{\text {eco }}$. We can offer no explanation for this longterm decline in peak LAI. Interestingly, when annual $R_{\text {eco }}$ totals are separated into growing season and non-growing sea- son periods, the declining trend is only found in the growing season $R_{\text {eco }}$, which comprises $71 \%$ ( $\pm 3 \% \mathrm{CI}$ ) of the annual total. This emphasises the strong linkage between $R_{\text {eco }}$ and GPP within a growing season.

Growing season length has also been shown to be an important control factor in ecosystem $\mathrm{C}$ balance both at the individual site level (e.g. Carrara et al., 2003; Granier et al., 2008) and across a range of forest types (Baldocchi and $\mathrm{Xu}$, 2005). However, at this site neither NEP nor GPP was correlated with onset of growing season or length of growing season. This is similar to the findings of Dunn et al. (2007) who found no correlation between longer growing seasons and net $\mathrm{C}$ uptake (at a boreal black spruce forest), which they suggested was due to corresponding increases in ecosystem respiration offsetting increased GPP during longer growing seasons.

The importance of indirect climatic events such as insectinduced canopy defoliation is becoming evident from the growing network of long-term forest EC studies (Allard et al., 2008; Pilegaard et al., 2011). In this study the observed reduction in NEP that occurred in 2009 and 2010 could in part be attributed to the major outbreak of defoliating moth caterpillars, which caused a significant reduction in peak LAI. In addition, there are likely to have been some effects of the oak powdery mildew (Erysiphe alphitoides) infection of leaf regrowth on a number of oak trees within the study 
area in 2009 and 2010 (Heinemeyer at al., 2012) and the occurrence of a late and damaging air frost on day 127 in 2010.

Understanding the determinants of $R_{\text {eco }}$ is complicated because it is governed by several different above- and belowground processes, each responding to a set of environmental variables. The ratio of $R_{\text {eco }} / \mathrm{GPP}$ was relatively constant $(0.76 \pm 0.02 \mathrm{CI})$ and was similar to the average value of 0.80 reported by Law et al. (2002) for a range of forest types. In the absence of auxiliary measurements, it is impossible to separate total $R_{\text {eco }}$ into its different components. However in a parallel study at the same site, between 2007 and 2010, soil $\mathrm{CO}_{2}$ efflux was estimated to be $740 \pm 43 \mathrm{~g} \mathrm{C} \mathrm{m}^{-2} \mathrm{yr}^{-1}$ (Heinemeyer at al., 2012), accounting for $\sim 53 \%$ of total $R_{\text {eco }}$ over the same period. Other studies have estimated a larger contribution by soil autotrophs and heterotrophs to total $R_{\text {eco }}$. For example, Knohl et al. (2008) reported a range of $79-88 \%$ for another temperate deciduous forest. At the annual scale, mean monthly air temperature explained most of the annual variability in $R_{\text {eco }}\left(r^{2}=0.81\right.$, Table 5$)$. Nongrowing season (winter) $R_{\text {eco }}$ was tightly correlated with air temperature (mean $r^{2}=0.77$ ), which we attribute to the dominance of heterotrophic respiration during this period. During the growing season the relationship was weaker and varied substantially between years because of the influence of soil moisture. There was more interannual variation in this relationship during the growing season $\left(r^{2}=0.39\right)$. This type of response has been demonstrated across a range of other forest sites (Law et al., 2002) and is probably because, under conditions of moderate reduced water content, microbial respiration is limited by the diffusion of soluble organic substrates (Epron et al., 1999), particularly in the near-surface layers. The autotrophic respiration component is less likely to be affected by moderate reductions in water content because of the deeper rooting depth (Borken et al., 2006).

The 12-yr continuous dataset presented here for the first time shows that this deciduous forest ecosystem located in southeast Britain acted as a substantial sink for carbon, with a mean up take of $486 \mathrm{~g} \mathrm{C} \mathrm{m}^{-2} \mathrm{yr}^{-1}$ (95\% CI of $\pm 73 \mathrm{~g} \mathrm{C} \mathrm{m}^{-2} \mathrm{yr}^{-1}$ ). Our EC-based estimates of NEP are relatively closely matched by mensuration-based estimates, providing confidence in our measurements. Year-toyear variation in NEP was largely explained by changes in the contributory, yet opposing, partitioned fluxes of GPP and $R_{\text {eco }}$, and the main biological and environmental drivers of these have been discussed. The study has also identified the important effect that biotic damage such as insect defoliation can have on the carbon flux dynamics of forests.

\section{Copyright statement}

${ }^{(C)}$ Crown copyright 2012.
Acknowledgements. The authors would like to thank all staff and students at Forest Research who have worked on this project. Our special thanks to Rona Pitman for assisting with running the site and contributing to litterfall analysis, Eric Casella for biometric tree harvest data, and to Samantha Broadmeadow for her technical assistance. We would also like to thank staff at the School of GeoSciences, University of Edinburgh, especially Robert Clement, for their advice and guidance, particularly in the use of EdiRe software. We are grateful to the Forestry Commission for funding this work.

Edited by: P. Stoy

\section{References}

Allard, V., Ourcival, J. M., Rambal, S., Joffree, R., and Rocheteau, A.: Seasonal and annual variation of carbon exchange in an evergreen Mediterranean forest in southern France, Glob. Change Biol., 14, 714-725, 2008.

Alton, P. B.: Reduced carbon sequestration in terrestrial ecosystems under overcast skies compared to clear skies, Agr. Forest Meteorol., 148, 1641-1653, 2008.

Aubinet, M., Grelle, A., Ibrom, A., Rannik, U., Moncrieff, J., Foken, T., Kowalaski, A. S., Martin, P. H., Berbigier, P., Bernhofer, C., Clement, R., Elbers, J., Granier, A., Grunwald, T., Morgenstern, K., Pilegaard, K., Rebmann, C., Snijders, W., Valentini, R., and Vesala, T.: Estimates of the annual net carbon and water exchanges of forests: the EUROFLUX methodology, Adv. Ecol. Res., 30, 113-175, 2000.

Baldocchi, D. D.: 'Breathing' of the terrestrial biosphere: lessons learned from a global network of carbon dioxide flux measurement systems, Aust. J. Bot., 56, 1-26, 2008.

Baldocchi, D. D. and Xu, L.: Carbon exchange of deciduous broadleaved forests in temperate and mediterranean regions, in: Carbon Balance of Forest Biomes, edited by: Jarvis, P. J. and Griffiths, H., Taylor \& Francis, Oxford, 187-216, 2005.

Baldocchi, D. D., Falge, E., Gu, L. H., Olson, R., Hollinger, D., Running, S., Anthoni, P., Bernhofer, C., Davis, K., Evans, R., Fuentes, J., Goldstein, A., Katul, G., Law, B., Lee, X. H., Malhi, Y., Meyers, T., Munger, W., Oechel, W., Paw, K. T., Pilegaard, K., Schmid, H. P., Valentini, R., Verma, S., Vesala, T., Wilson, K., and Wofsy, S.: FLUXNET: A new tool to study the temporal and spatial variability of ecosystem-scale carbon dioxide, water vapor, and energy flux densities, B. Am. Meteorol. Soc., 82, 2415-2434, 2001.

Barford, C. C., Wofsy, S. C., Goulden, M. L., Munger, J. W., Pyle, E. H., Urbanski, S. P., Hutyra, L., Saleska, S. R., Fitzjarrald, D., and Moore, K.: Factors controlling long- and short-term sequestration of atmospheric $\mathrm{CO}_{2}$ in a mid-latitude forest, Science, 294, 1688-1691, 2001.

Benham, S. E., Vanguelova, E. I., and Pitman, R. M.: Short and long term changes in carbon, nitrogen and acidity in the forest soils under oak at the Alice Holt Environmental Change Network site, Sci. Total Environ., 421-422, 82-93, doi:10.1016/j.scitotenv.2012.02.004, 2012.

Black, K., Bolger, T., Davis, P., Nieuwenhuis, M., Reidy, B., Saiz, G., Tobin, B., and Osborne, B.: Inventory and eddy covariancebased estimates of annual carbon sequestration in a Sitka spruce 
(Picea sitchensis (Bong.) Carr.) forest ecosystem, Eur. J. For. Res., 126, 167-178, 2007.

Borken, W., Savage, K., Davidson, E. A., and Trumbore, S. E.: Effects of experimental drought on soil respiration and radiocarbon efflux from a temperate forest soil, Glob. Change Biol., 12, 177193, 2006.

Broadmeadow, M. S. J. and Matthews, R. W.: Forests, carbon and climate change: the UK contribution, Forestry Commission Information Note 48, Forestry Commission, Edinburgh, 2003.

Butt, N., Campbell, G., Malhi, Y., Morecroft, M., Fenn, K., and Thomas, M.: Initial results from establishment of a long-term broadleaf monitoring plot at Wytham Woods, Oxford, UK, University of Oxford report, Oxford, 2009.

Carrara, A., Kowalski, A. S., Neirynck, J., Janssens, I. A., Yuste, J. C., and Ceulemans, R.: Net ecosystem $\mathrm{CO}_{2}$ exchange of mixed forest in Belgium over 5 years, Agr. Forest Meteorol. 119, 209227, 2003.

Ciais, P., Reichstein, M., Viovy, N., Granier, A., Ogée, J., Allard, V., Aubinet, M., Buchmann, N., Bernhofer, C., Carrara, A., Chevallier, F., De Noblet, N., Friend, A. D., Friedlingstein, P., Grünwald, T., Heinesch, B., Keronen, P., Knohl, A., Krinner, G., Loustau, D., Manca, G., Matteucci, G., Miglietta, F., Ourcival, J. M., Papale, D., Pilegaard, K., Rambal, S., Seufert, G., Soussana, J. F., Sanz, M. J., Schulze, E. D., Vesala, T., and Valentini, R.: Europe-wide reduction in primary productivity caused by the heat and drought in 2003, Nature, 437, 529-533, 2005.

Clement, R. J., Jarvis, P. G., and Moncrieff, J. B.:, Carbon dioxide exchange of a Sitka Spruce plantation in Scotland over five years, Agr. Forest Meteorol. 153, 106-123, 2012.

Dunn, A. L., Barford, C. C., Wofsy, S. C., Goulden, M. L., and Daube, B. C.: A long-term record of carbon exchange in a boreal black spruce forest: means, responses to interannual variability, and decadal trends, Glob. Change Biol., 13, 577-590, 2007.

Epron, D., Farque, L., Lucot, E., and Badot, P. M.: Soil $\mathrm{CO}_{2}$ efflux in a beech forest: dependence on soil temperature and soil water content, Ann. For. Sci., 56, 221-226, 1999.

Falge, E., Baldocchi, D., Olson, R. J., Anthoni, P., Aubinet, M., Bernhofer, C., Burba, G., Ceulemans, R., Clement, R., Dolman, H., Granier, A., Gross, P., Grünwald, T., Hollinger, D., Jensen, N.-O., Katul, G., Keronen, P., KowalskI, A., Ta Lai, C., Law, B. E., Meyers, T., Moncrieff, J., Moors, E., Munger, J. W., Pilegaard, K., Rannik, Ü., Rebmann, C., Suyker, A., Tenhunen, J., Tu, K., Verma, S., Vesala, T., Wilson, K., and Wofsy, S.: Gap filling strategies for defensible annual sums of net ecosystem exchange, Agr. Forest Meteorol., 107, 43-69, 2001.

Gough, C. M., Vogel, C. S., Schmid, H. P., Su, H.-B., and Curtis, P. S.: Multi-year convergence of biometric and meteorological estimates of forest carbon storage, Agr. Forest Meteorol., 148, 158-170, 2008.

Gower, S. T., Kucharik, C. J., and Norman, J. M.: Direct and indirect estimation of leaf area index, $\mathrm{f}(\mathrm{APAR})$, and net primary production of terrestrial ecosystems, Remote Sens. Environ., 70, 29-51, 1999.

Granier, A., Bréda, N., Longdoz, B., Gross. P., and Ngao, J.: Ten years of fluxes and stand growth in a young beech forest at Hesse, North-eastern France, Ann. For. Sci., 65, 704, 2008.

Greco, S. and Baldocchi, D. D.: Seasonal variation of $\mathrm{CO}_{2}$ and water vapour exchange rates over a temperate deciduous forest, Glob. Change Biol., 2, 183-197, 1996.
Heinemeyer, A., Wilkinson, M., Vargas, R., Subke, J.-A., Casella, E., Morison, J. I. L., and Ineson, P.: Exploring the "overflow tap" theory: linking forest soil $\mathrm{CO}_{2}$ fluxes and individual mycorrhizosphere components to photosynthesis, Biogeosciences, 9, 79-95, doi:10.5194/bg-9-79-2012, 2012.

Hignett, P.: Corrections to temperature measurements with a sonic anemometer, Bound.-Lay. Meteorol., 67, 175-187, 1992.

Hirata, R., Hirano, T., Saigusa, N., Fujinuma, Y., Inukai, K., Kitamori, Y., Takahashi, Y., and Yamamoto, S.: Seasonal and interannual variations in carbon dioxide exchange of a temperate larch forest, Agr. Forest Meteorol., 147, 110-124, 2007.

Hollinger, D. Y., Kelliher, F., Byers, J. N., Hunt, J. E., McSeveny, T. M., and Weir, P. L.: Carbon dioxide exchange between an undisturbed old-growth temperate forest and the atmosphere, Ecology, 75, 134-150, 1994.

ICP Forests (International co-operative programme on assessment and monitoring of air pollution effects on forests), Part XI: Sampling and analysis of litterfall, vTI-Institute for World Forestry, Hamburg, 2004.

Ilvesniemi, H., Levula, J., Ojansuu, R., Kolari, P., Kulmala, L., Pumpanen, J., Launiainen, S., Vesala, T., and Nikinmaa, E.: Long-term measurements of the carbon balance of a boreal Scots pine dominated forest ecosystem, Boreal Environ. Res., 14, 731753, 2009.

Ito, S., Saigusa, N., Murayama, S., and Yamamoto, S.: Modelling of gross and net carbon dioxide exchange over a cool-temperate deciduous broad-leaved forest in Japan: Analysis of seasonal and interannual change, Agr. Forest Meteorol., 134, 122-134, 2005.

Jenkins, J. P., Richardson, A. D., Braswell, B. H., Ollinger, S. V., Hollinger, D. Y., and Smith, M.-L.: Refining light-use efficiency calculations for a deciduous forest canopy using simultaneous tower-based carbon flux and radiometric measurements, Agr. Forest Meteorol., 143, 64-79, 2007.

Kirby, K. J.: The trees in the woods Wytham Woods, in: Oxford's Ecological Laboratory, edited by: Savill, P. S., Perrins, C. M., Kirby, K. J., and Fisher, N., Oxford University Press, Oxford, 57-74, 2010.

Knohl, A., Søe, A. R. B., Kutsch, W. L., Göckede, M., and Buchmann, N.: Representative estimates of soil and ecosystem respiration in an old beech forest, Plant Soil, 302, 189-202, 2008.

Kormann, R. and Meixner, F. X.: An analytical footprint model for non-neutral stratification, Bound.-Lay. Meteorol., 99, 207-224, 2001.

Kosugi, Y., Tanaka, H., Takanashi, S., Matsuo, N., Ohte, N., Shibata, S., and Tani, M.: Three years of carbon and energy fluxes from Japanese evergreen broad-leaved forest, Agr. Forest Meteorol., 132, 329-343, 2005.

Kutsch, W., Liu, C. J., Hoermann, G., and Herbst, M.: Spatial heterogeneity of ecosystem carbon fluxes in a broadleaved forest in Northern Germany, Glob. Change Biol., 11, 70-88, 2005.

Law, B. E., Falge, E., Gu, L., Baldocchi, D. D., Bakwin, P., Berbigier, P., Davis, K., Dolman, A. J., Falk, M., Fuentes, J. D., Goldstein, A., Granier, A., Grelle, A., Hollinger, D., Janssens, I. A., Jarvis, P., Jensen, N.-O., Katul, G., Mahli, Y., Matteucci, G., Meyers, T., Monson, R., Munger, W., Oechel, W., Olson, R., Pilegaard, K., Paw, K. T., Thorgeirsson, H., Valentini, R., Verma, S., Vesala, T., Wilson, K., and Wofsy, S.: Environmental controls over carbon dioxide and water vapor exchange of terrestrial vegetation, Agr. Forest Meteorol., 113, 96-120, 2002. 
Lenschow, D. H. and Raupach, M. R.: The attenuatation of fluctuations in scalar concentrations through sampling tubes, J. Geophys. Res., 96D, 15259-15268, 1991.

Leuning, R. and Moncrieff, J.: Eddy-covariance $\mathrm{CO}_{2}$ flux measurements using open- and closed-path $\mathrm{CO}_{2}$ analysers: corrections for analysers water vapour sensitivity and damping of fluctuations in air sampling tubes, Bound.-Lay. Meteorol., 53, 63-76, 1990.

Lloyd, J. and Taylor, J. A.: On the temperature dependence of soil respiration, Funct. Ecol., 8, 315-323, 1994.

Longdoz, B., Granier, A., Loustau, D., Bakker, M., Delzon, S., Kowalski, A. S., Rambal, S., Dufrene, E., Bonal, D., and Nouvellon, Y.: Environmental control of carbon fluxes in forest ecosystems in France: a comparison of temperate, mediterranean and tropical forests, in: Forests, Carbon Cycle and Climate Change, edited by: Loustau, D., Éditions Quae, Versailles, 27-53, 2010.

Luyssaert, S., Inglima, I., Jung, M., Richardson, A. D., Reichstein, M., Papale, D., Piao, S. L., Schulze, E. D., Wingate, L., Matteucci, G., Aragao, L. E. O. C., Aubinet, M., Beers, C., Bernhofer C., Black, G. K., Bonal, D., Bonnefond, J. M., Chambers, J., Ciais, P., Cook, B., Davis, K. S., Dolman, A. J., Gielen, B., Goulden, M., Grace, J., Granier, A., Grelle, A., Griffis, T., Grünwald, T., Guidolotti, G., Hanson, P. J., Harding, R., Hollinger, D. Y., Hutyra, L. R., Kolari, P., Kruijt, B., Kutsch, W. L., Lagergren, F., Laurila, T., Law, B., Le Maire, G., Lindroth, A., Loustau, D., Malhi, Y., Mateu, J., Migliavacca, M., Misson, L., Montagnani, L., Moncrieff, J., Moors, E. J., Munger, J. W., Nikinmaa, E., Ollinger, S. V., Pita, G., Rebmann, C., and Roupsard, O.: $\mathrm{CO}_{2}$ balance of boreal, temperate, and tropical forests derived from a global database, Glob. Change Biol. 13, 25092537, 2007

McKay, H., Hudson, J. B., and Hudson, R. J.: Woodfuel Resources in Britain FES/B/W3/00787/REP/2. DTI./Pub URN 03/1436, Forestry Commission and Forestry Contracting Association, Edinburgh and Lairg, 2003.

Massman, W. J.: The attenuation of concentration fluctuations in turbulent flow through a tube, J. Geophys. Res., 96D, 1526915273, 1991.

Moffat, A. M., Papale, D., Reichstein, M., Hollinger, D. Y., Richardson, A. D., Barr, A. G., Beckstein, C., Braswell, B. H., Churkina, G., Desai, A. R., Falge, E., Grove, J. H., Heimann, M., Hui, D., Jarvis, A. J., Kattge, J., Noormets, A., and Stauch, V. J.: Comprehensive comparison of gap-filling techniques for eddy covariance net carbon fluxes, Agr. Forest Meteorol., 147, 209-232, 2007.

Moncrieff, J. B., Massheder, J. M., de Bruin, H., Elbers, J., Friborg, T., Heusinkveld, B., Kabat, P., Scott, S., Soegaard, H., and Verhoef, A.: A system to measure surface fluxes of momentum sensible heat, water vapour and carbon dioxide, J. Hydrol., 188-189, 589-611, 1997.

Moore, C. J.: Frequency response corrections for eddy correlation systems, Bound.-Lay. Meteorol., 37, 17-35, 1986.

Moore, P. T., Van Miegroet, H., and Nicholas, N. S.: Relative role of understory and overstory in carbon and nitrogen cycling in a southern Appalachian spruce-fir forest, Can. J. Forest Res., 37, 2689-2700, 2007.

Morison, J., Matthews, R., Miller, G., Perks, M., Randle, T., Vanguelova, E., White, M., and Yamulki, S.: Understanding the carbon and greenhouse gas balance of forests in Britain. Forestry Commission Research Report, Forestry Commission, Edinburgh,
149 pp., 2012.

Nabuurs, G. J., Masera, O., Andrasko, K., Benitez-Ponce, P., Boer, R., Dutschke, M., Elsiddig, E., Ford-Robertson, J., Frumhoff, P., Karjalainen, T., Krankina, O., Kurz, W. A., Matsumota, M., Oyhantcabal, W., Ravindranath, N. H., Sanz Sanchex, M. J., and Zhang, X.: Forestry, in: Climate Change 2007: Mitigation, Contribution of Working group III to the Fourth Assessment Report of the Intergovernmental Panel on Climate Change, edited by: Metz, B., Davidson, O. R., Bosch, P. R., Dave, R., and Meyer, L. A., Cambridge University Press, Cambridge, 541-584, 2007.

Noormets, A., McNulty, S. G., DeForest, J. L., Sun, G., Li, Q., and Chen, J. L: Drought during canopy development has lasting effect on annual carbon balance in a deciduous temperate forest, New Phytol., 179, 818-828, 2008.

Pan, Y., Birdsey, R. A., Fang, J., Houghton, R., Kauppi, P. E., Kurz, W. A., Phillips, O. L., Shvidenko, A., Lewis, S. L., Canadell, J. G., Ciais, P., Jackson, R. B., Pacala, S., McGuire, A. D., Piao, S., Rautiainen, A., Sitch, S., and Hayes, D.: A large and persistent carbon sink in the world's forests, Science, 19, 988-993, 2011.

Papale, D., Reichstein, M., Aubinet, M., Canfora, E., Bernhofer, C., Kutsch, W., Longdoz, B., Rambal, S., Valentini, R., Vesala, T., and Yakir, D.: Towards a standardized processing of Net Ecosystem Exchange measured with eddy covariance technique: algorithms and uncertainty estimation, Biogeosciences, 3, 571-583, doi:10.5194/bg-3-571-2006, 2006.

Pereira, J. S., Mateus, J. A., Aires, L. M., Pita, G., Pio, C., David, J. S., Andrade, V., Banza, J., David, T. S., Paço, T. A., and Rodrigues, A.: Net ecosystem carbon exchange in three contrasting Mediterranean ecosystems - the effect of drought, Biogeosciences, 4, 791-802, doi:10.5194/bg-4-791-2007, 2007.

Pilegaard, K., Ibrom, A., Courtney, M. S., Hummelshøj, P., and Jensen, N. O.: Increasing net $\mathrm{CO}_{2}$ uptake by a Danish beech forest during the period from 1996 to 2009, Agr. Forest Meteorol. 151, 934-946, 2011.

Pitman, R. M. and Broadmeadow, M. S. J.: Leaf area, biomass and physiological parameterisation of ground vegetation of lowland oak woodland, Internal Report to PPD, Forestry Commission, Edinburgh, 2001.

Pitman, R. M., Vanguelova, E. I., and Benham, S. E.: The effects of phytophagous insects on water and soil nutrient concentrations and fluxes through forest stands of the Level II monitoring network in the UK, Sci. Total Environ., 409, 169-181, 2010.

Powell, T. L., Bracho, R., Li, J. H., Dore, S., Hinkle, C. R., and Drake, B. G.: Environmental controls over net ecosystem carbon exchange of scrub oak in central Florida, Agr. Forest Meteorol., 141, 19-34, 2006.

Pyatt, D. G.: Soil classification, Forestry Commission Research Information Note 68/82/SSN, Forestry Commission, Edinburgh, 1982.

Reich, P. B.: Taking stock of forest carbon, Nature Clim. Change, 1, 346-347, 2011.

Reichstein, M., Falge, E., Baldocchi, D., Papale, D., Valentini, R., Aubinet, M., Berbigier, P., Bernhofer, C., Buchmann, N., Gilmanov, T., Granier, A., Grünwald, T., Havránková, K., Janous, D., Knohl, A., Laurela, T., Lohila, A., Loustau, D., Matteucci, G., Meyers, T., Miglietta, F., Ourcival, J. M., Rambal, S., Rotenberg, E., Sanz, M., Seufert, G., Vaccari, F., Vesala, T., and Yakir, D.: On the separation of net ecosystem exchange into assimilation and ecosystem respiration: review and improved algo- 
rithm, Glob. Change Biol., 11, 1-16, 2005.

Reichstein, M., Papale, D., Valentini, R., Aubinet, M., Bernhofer, C:, Knohl, A., Laurila, T., Lindroth, A., Moors, E., Pilegaard, K., and Seufert, G.: Determinants of terrestrial ecosystem carbon balance inferred from European eddy covariance flux sites, Geophys. Res. Lett., 34, L01402, doi:10.1029/2006GL027880, 2007.

Saigusa, N., Yamamoto, S., Murayama, S., and Kondo, H.: Interannual variability of carbon budget components in an AsiaFlux forest site estimated by long-term flux measurements, Agric. Forest Meteorol. 134, 4-16, 2005.

Saigusa, N., Yamamoto, S., Hirata, R., Ohtani, Y., Ide, R., Asanuma, J., Gamo, M., Hirano, T., Kondo, H., Kosugi, Y., Li, S. G., Nakai, Y., Takagi, K., Tani, M., and Wang, H.: Temporal and spatial variations in the seasonal patterns of $\mathrm{CO}_{2}$ flux in boreal, temperate, and tropical forests in East Asia, Agr. For. Meteorol., 148, 700713, 2008

Saunders, M., Tobin, B., Black, K., Niewuenhuis, M., and Osborne, B.: Thinning effects on the net ecosystem carbon exchange of a Sitka spruce forest are temperature-dependent, Agr. Forest Meteorol., 157, 1-10, 2012.

Schlich, W.: Working plan for the Alice Holt Forest, His Majesty's Stationery Office, London, 1905.

Schwalm, C. R., Black, T. A., Amiro, B. D., Arain, M. A., Barr, A. G., Bourque, C. P.-A., Dunn, A. L., Flanagan, L. B., Giasson, M.A., Lafleur, P. M., Margolis, H. A., McCaughey, J. H., Orchansky, A. L., and Wofsy, S. C.: Photosynthetic light use efficiency of three biomes across an east-west continental-scale transect in Canada, Agr. Forest Meteorol. 140, 269-286, 2006.

Sykes, J. M. and Lane, A. M. J. (Eds.): The UK Environmental Change Network: Protocols for standard measurements at terrestrial sites, The Stationery Office, London, 1996.
Teklemariam, T., Staebler, R. M., and Barr, A. G.: Eight years of carbon dioxide exchange above a mixed forest at Borden, Ontario, Agr. Forest Meteorol., 149, 2040-2053, 2009.

Thomas, M. V., Malhi, Y., Fenn, K. M., Fisher, J. B., Morecroft, M. D., Lloyd, C. R., Taylor, M. E., and McNeil, D. D.: Carbon dioxide fluxes over an ancient broadleaved deciduous woodland in southern England, Biogeosciences, 8, 1595-1613, doi:10.5194/bg-8-1595-2011, 2011.

Unger, S., Máguas, C., Pereira, J. S., Aires, L. M., David, T. S., and Werner, C.: Partitioning carbon fluxes in a Mediterranean oak forest to disentangle changes in ecosystem sink strength during drought, Agr. Forest Meteorol., 149, 949-961, 2009.

Urbanski, S., Barford, C., Wofsy, S., Kucharik, C., Pyle, E., Budney, J., McKain, K., Fitzjarrald, D., Czikowsky, M., and Munger, J. W.: Factors controlling $\mathrm{CO}_{2}$ exchange on timescales from hourly to decadal at Harvard forest, J. Geophys. Res., 112, GO2020, doi:10.1029/2006JG000293, 2007.

Valentini, R., Matteucci, G., Dolman, A. J, Schulze. E.-D., Rebmann, C., Moors, E. J., Granier, A., Gross, P., Jensen, N. O., Pilegaard, K., Lindroth, A., Grelle, A., Bernhofer, C., Grünwald, T., Aubinet, M., Ceulemans, R., Kowalski, A. S., Vesala, T., Rannik, Ü., Berbigier, P., Loustau, D., Guð̋mundsson, J., Thorgeirsson, H., Ibrom, A., Morgenstern K., Clement, R., Moncrieff, J., Montagnani, L., Minerbi, S., and Jarvis, P. G.: Respiration as the main determinant of European forests carbon balance, Nature, 404, 861-865, 2000.

Van der Molen, M. K., Gash, J. H. C., and Elbers, J. A.: Sonic anemometer (co)sine responses and flux measurements: II. The effect of introducing an angle of attack dependant calibration, Agr. Forest Meteorol., 122, 95-109, 2004. 